Antarctic Science 33(4), 428-455 (2021) @ The Author(s), 2021. Published by Cambridge University Press on behalf of Antarctic Science Ltd. This is an Open Access article, distributed under the terms of the Creative Commons Attribution licence (http:// creativecommons.org/licenses/by/4.0/), which permits unrestricted re-use, distribution, and reproduction in any medium, provided the original work is properly cited.

doi:10.1017/S0954102021000237

\title{
Ice-free valleys in the Neptune Range of the Pensacola Mountains, Antarctica: glacial geomorphology, geochronology and potential as palaeoenvironmental archives
}

\author{
DAVID SMALL (1) ${ }^{1}$, MICHAEL J. BENTLEY (1) ${ }^{1}$, DAVID J.A. EVANS ${ }^{1}$, ANDREW S. HEIN ${ }^{2}$ and \\ STEWART P.H.T. FREEMAN $\mathbb{D}^{3}$ \\ ${ }^{1}$ Department of Geography, Durham University, Durham, DH1 3LE, UK \\ ${ }^{2}$ School of Geosciences, University of Edinburgh, Edinburgh, EH8 9XP, UK \\ ${ }^{3}$ Scottish Universities Environmental Research Centre, East Kilbride, G75 0QF, UK \\ david.p.small@durham.ac.uk
}

\begin{abstract}
We describe the glacial geomorphology and initial geochronology of two ice-free valley systems within the Neptune Range of the Pensacola Mountains, Antarctica. These valleys are characterized by landforms associated with formerly more expanded ice sheet(s) that were at least $200 \mathrm{~m}$ thicker than at present. The most conspicuous features are areas of supraglacial debris, discrete debris accumulations separated from modern-day ice and curvilinear ridges and mounds. The landsystem bears similarities to debris-rich cold-based glacial landsystems described elsewhere in Antarctica and the Arctic where buried ice is prevalent. Geochronological data demonstrate multiple phases of ice expansion. The oldest, occurring $>3 \mathrm{Ma}$, overtopped much of the landscape. Subsequent, less expansive advances into the valleys occurred $>2 \mathrm{Ma}$ and $>\sim 1 \mathrm{Ma}$. An expansion of some local glaciers occurred $<250 \mathrm{ka}$. This sequence of glacial stages is similar to that described from the northernmost massif of the Pensacola Mountains (Dufek Massif), suggesting that it represents a regional signal of ice-sheet evolution over the Plio-Pleistocene. The geomorphological record and its evolution over millions of years makes the Neptune Range valleys an area worthy of future research and we highlight potential avenues for this.
\end{abstract}

Received 15 January 2021, accepted 23 March 2021

Key words: cold-based glaciation, cosmogenic nuclide dating, glacial geomorphology, ice-sheet evolution, Weddell Sea

\section{Introduction}

Terrestrial archives that can inform past environmental change are rare in Antarctica because $<1 \%$ of the Antarctic continent is ice free. The largest contiguous ice-free areas, the McMurdo Dry Valleys (MDVs), have probably remained ice free since the Miocene (Denton \& Sugden 2005, Lewis et al. 2007) and contain a rich geomorphological record. These valleys are characterized by a range of climatic zones that contain distinct landform assemblages (e.g. Marchant \& Head 2007) and have informed reconstructions of past cryospheric and environmental change over multimillion-year timescales (e.g. Sugden et al. 1995, Marchant et al. 2002, Swanger et al. 2010, 2011, 2017).

Ice-free valley systems that exist elsewhere in Antarctica also have potential as long-term geomorphological and palaeoenvironmental archives (e.g. Bockheim et al. 1989, Hodgson et al. 2012, Bibby et al. 2016). To realize this potential, it is essential that the relevant landforms be described and mapped so that process-form analogues can be identified and their palaeoenvironmental significance assessed. A geochronological framework can shed light on the potential length of the archive(s) as well as the timing of events and rates of processes: this allows relevant research questions to be developed for future work. The purpose of this paper is to describe a potentially valuable geomorphic record of past cryospheric change from ice-free valley systems within the Neptune Range of the Pensacola Mountains in the southern Weddell Sea sector of Antarctica (Fig. 1). We present initial geomorphological mapping and interpretation of the observed landforms with reference to potential analogues in the MDVs and other similar climatic settings. Preliminary geochronological data $\left({ }^{10} \mathrm{Be}\right.$ and ${ }^{26} \mathrm{Al}$ exposure ages) are presented to demonstrate the potential length of the record preserved in the Neptune Range dry valley systems.

\section{Regional setting and wider significance}

The Neptune Range is a massif within the Pensacola Mountains in the south-east portion of the Weddell 


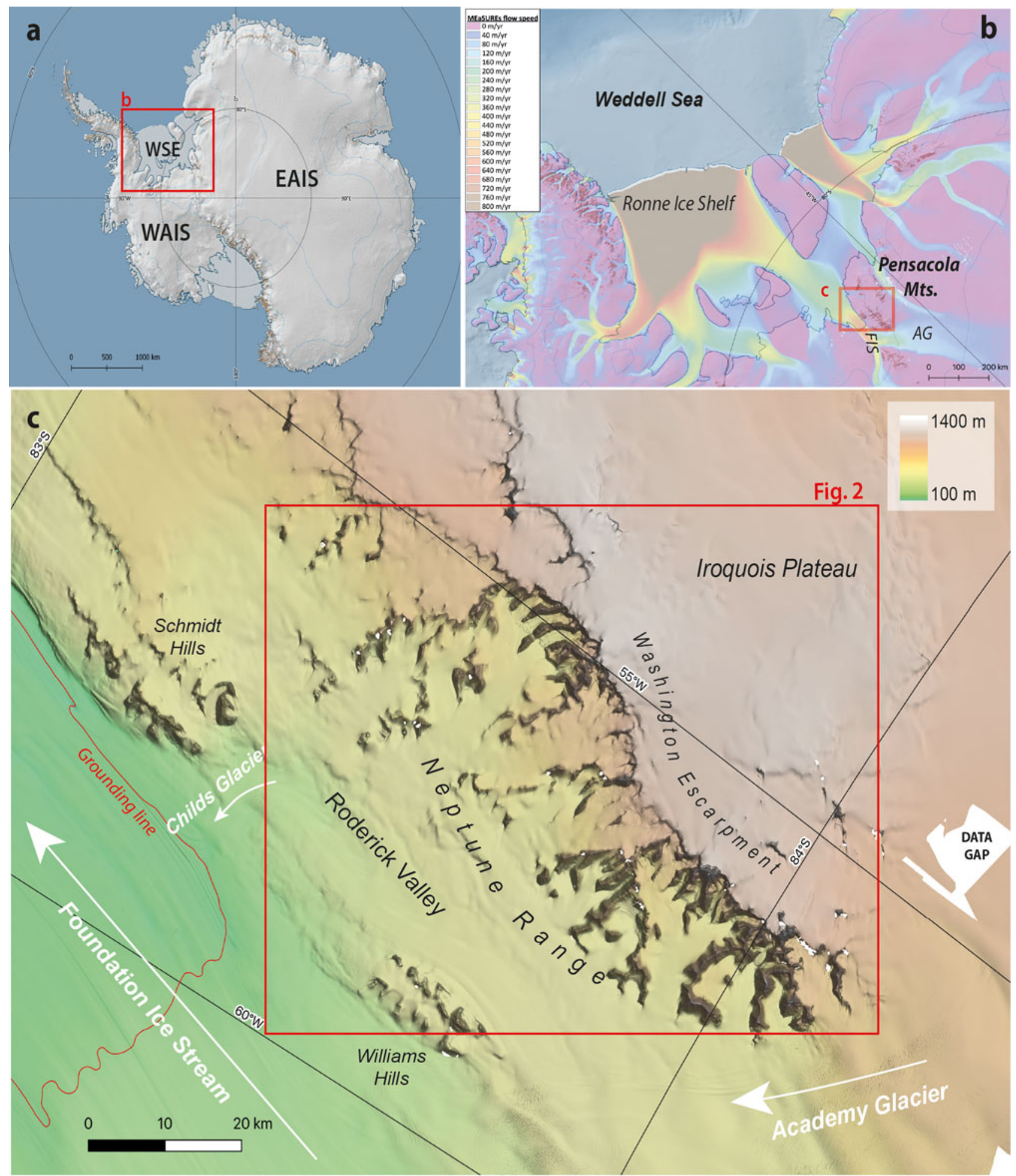

Fig. 1. a. Location map showing the Weddell Sea Embayment (WSE) in the context of the Antarctic continent. EAIS = East Antarctic Ice Sheet; WAIS = West Antarctic Ice Sheet. b. Current ice-sheet configuration and location of the Pensacola Mountains in the WSE with measured flow velocities (Rignot et al. 2011). AG = Academy Glacier; FIS = Foundation Ice Stream. c. Hill-shaded digital elevation model (Reference Elevation Model of Antarctica $8 \mathrm{~m}$; Howat et al. 2019) of the Neptune Range and main geographical features mentioned in the text. 
Sea embayment (Fig. 1). The Pensacola Mountains are dominated by folded sandstones, mudstones, conglomerates and limestones, with minor igneous rocks exposed in their western part (Schmidt et al. 1978). The Neptune Range consists of the Washington Escarpment with associated ridges and valleys, the Iroquois Plateau, the Schmidt Hills and the Williams Hills. These latter two massifs are located on the eastern margin of the Foundation Ice Stream (FIS) and are separated from the Washington Escarpment by the ice-filled Roderick Valley. The Washington Escarpment trends north-west to south-east for $>100 \mathrm{~km}$ and, at its southern end, the Academy Glacier flows from the polar plateau and is confluent with the FIS. To the east of the Washington Escarpment the Iroquois Plateau comprises a large snowfield at an elevation of $\sim 1400 \mathrm{~m}$. Outlet glaciers from this snowfield overtop the Washington Escarpment in numerous places and flow west into Roderick Valley and, via Childs Glacier, into the trunk of the FIS (Fig. 1).

In several places, peaks on the Washington Escarpment are sufficiently high to prevent overriding by ice from the Iroquois Plateau (Fig. 2). In the lee of these highest peaks are several ice-free valleys that are blocked at their entrances by ice lobes that spill into the lower valleys from outlet glaciers flowing from the plateau towards Roderick Valley. There are two main areas where such valleys occur. First, in the lee of Nelson Peak (1605 m), Miller Valley and contiguous ice-free areas occupy $\sim 20 \mathrm{~km}^{2}$ (Figs $2 \& 3$ ). Second, in the lee of the highest peak in the Neptune Range, Mount Hawkes (1975 m), are several unnamed valleys; the largest of these, unofficially termed South Hawkes Valley (SHV), Central Hawkes Valley (CHV) and North Hawkes Valley (NHV), have a combined area of $\sim 40 \mathrm{~km}^{2}$ (Figs $2 \& 4$ ).

Modelled mean annual temperatures in this region are $\sim-27^{\circ} \mathrm{C}$ (Van Wessem et al. 2014), and the Neptune Range is identified as an area of persistent wind scour, suggesting close to zero or slightly negative surface mass balance (Das et al. 2013). Given the cold temperatures and low ice-surface velocities $\left(<10 \mathrm{~m} \mathrm{yr}^{-1}\right.$; Rignot et al. 2011), cold-based ice is expected to be widespread throughout the region. Noticeably, throughout the Neptune Range there are accumulations of supraglacial debris at numerous ice-marginal locations (Fig. 2). Current datasets do not fully resolve the bed topography within the Neptune Range, so it is not known whether ice within the ice-filled valleys is sufficiently thick to produce widespread pressure-induced melting and thus entrain significant amounts of debris at its bed by regelation processes. That said, ice acceleration where it spills over the Washington Escarpment could initiate erosion and subglacial debris entrainment due to localized development of strain heating (e.g. Clarke et al. 1977, Evans \& Rea 2003). Additionally, cold-based ice can entrain some subglacial debris by interfacial water film regelation (e.g. Cuffey et al. 2000) and debris can be sourced directly from rock fall onto the ice surface (e.g. Swanger et al. 2011). Another common source of significant debris-rich ice facies in polar glacier margins is apron entrainment or sub-marginal freeze-on (net adfreezing), the latter being effective during periods of increased subglacial melting beneath thicker ice up-flow (cf. Shaw 1977, Evans 1989, 2009, Fitzsimons 2003). Regardless of the precise origin, debris-rich ice facies may be thickened by fold/thrust stacking and compression (Hambrey \& Fitzsimons 2010), especially in areas where ablation is dominant (cf. blue ice moraines), as is expected in the Neptune Range.

Antarctic dry valleys such as the MDVs are controlled by wind-driven sublimation with valley floors at lower elevations than the surrounding ice. The Neptune Valleys differ because the valley floors rise to the east, away from the ice front (Figs $3 \& 4$ ). The existence of these valleys may, therefore, be due to the driving stress being insufficient to advance ice further into the valleys. Alternatively, the ice-front positions may be controlled by a combination of ice dynamics and ablation. Nevertheless, despite these potential differences and their relatively small size, the Neptune Valleys, because they are located at $\sim 84^{\circ} \mathrm{S}$, represent some of the southernmost ice-free valley systems in the Weddell Sea Embayment, and they contain a rich geomorphic record that has not, to our knowledge, been described or investigated in any detail (cf. Schmidt et al. 1978).

\section{Miller Valley}

Miller Valley $\left(83.65^{\circ} \mathrm{S}, 55.21^{\circ} \mathrm{W}\right)$ is located to the north-west of Nelson Peak (Figs 2 \& 3). Its eastern flank is formed by the upper portion of Brown Ridge, on the other side of which an outlet glacier overtops the Washington Escarpment. The upper headwall of Miller Valley is formed by Nelson Peak and its outliers. Miller Valley widens from its entrance at $\sim 720 \mathrm{~m}$ above sea level ( $\mathrm{m}$ a.s.1.) and is separated from a smaller unnamed valley by a spur that extends from Brown Ridge. To the south of the valley a cirque hosts a small glacier. The upper portion of Miller Valley rises steeply to another small upper cirque at $\sim 1150 \mathrm{~m}$ a.s.l. beneath Nelson Peak. The floor of the valley is characterized by relatively coarse unconsolidated materials with no bedrock outcrops. Some bedrock does outcrop on spurs on the valley sides. Katabatic winds coming off the Iroquois Plateau are funnelled along Miller Valley to produce a blue ice ablation zone on the tongue of ice that spills into the valley entrance (Fig. 3).

\section{Hawkes Valleys}

The three main Hawkes Valleys $\left(83.91^{\circ} \mathrm{S}, 56.24^{\circ} \mathrm{W}\right)$ are located towards the upper end of Jones Valley (Fig. 2), a 


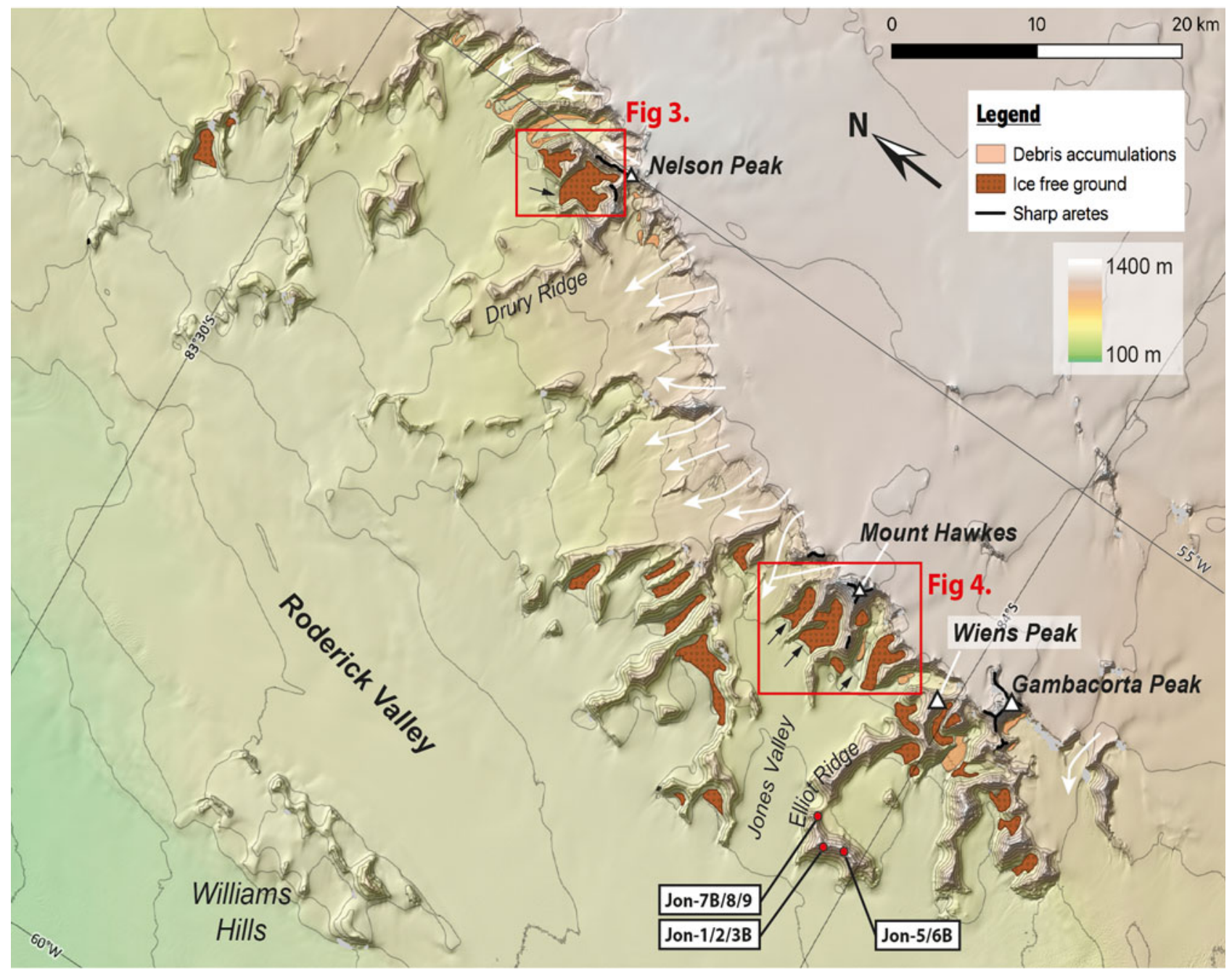

Fig. 2. Location map of Washington Escarpment showing geographical features mentioned in the text, major ice-free areas, debris accumulations and sharp ridge crests indicative of alpine-like topography. White arrows denote main points where ice from Iroquois Plateau overtops the escarpment. Small, black arrows indicate lobes of ice that spill back to block the entrances of the valleys described in this study. Red dots indicate locations of cosmogenic nuclide samples from the crest of Elliot Ridge. Background imagery is the hill-shaded Reference Elevation Model of Antarctica $8 \mathrm{~m}$ digital elevation model (Howat et al. 2019).

major valley with an east-west ice gradient that connects ice spilling over from the Iroquois Plateau to the Roderick Valley. Both $\mathrm{CHV}$ and NHV have their entrances blocked by tongues of blue ice ( $\sim 760$ and $\sim 800 \mathrm{~m}$ a.s.l., respectively) that spill back from ice in Jones Valley (Fig. 4). From the ice front, the valleys extend for $4.0 \mathrm{~km}(\mathrm{CHV})$ and $2.5 \mathrm{~km}(\mathrm{NHV})$, with the upper valley floors at $\sim 980 \mathrm{~m}$ a.s.l. (CHV) and $880 \mathrm{~m}$ a.s.l. (NHV) (Fig. 4). Both of these valleys are simple linear features with cirque-like headwalls and steep, rectilinear, debris-mantled slopes on both sides. They are $\sim 1.2$ and $\sim 0.7 \mathrm{~km}$ wide, respectively. Their floors, as well as the vast majority of the valley sides, are characterized by unconsolidated material with very rare bedrock outcrops. SHV differs (Fig. 4), as its main ice-free area comprises a gently sloping bench that is $\sim 500 \mathrm{~m}$ wide and situated $\sim 150-200 \mathrm{~m}$ above a narrow, $\sim 3 \mathrm{~km}$-long,
U-shaped valley. The western end of this valley is blocked by an ice tongue at $\sim 650 \mathrm{~m}$ a.s.l.; however, at its eastern end an outlet glacier from the Iroquois Plateau overtops the escarpment, forming an ice fall $\sim 280 \mathrm{~m}$ in height with its debris-covered terminus extending to within $\sim 100 \mathrm{~m}$ of the ice tongue at the western valley entrance. To the north of this glacier are steep bedrock slopes and several cirques. The main ice-free bench slopes upwards from west to east (800-1140 m a.s.1.), and its southern flank is composed of steep debris-mantled slopes with two smaller re-entrant side valleys that host small glaciers.

\section{Methods}

Brief fieldwork ( $<1$ day) in the Miller Valley and NHV during the 2009-2010 field season highlighted the 


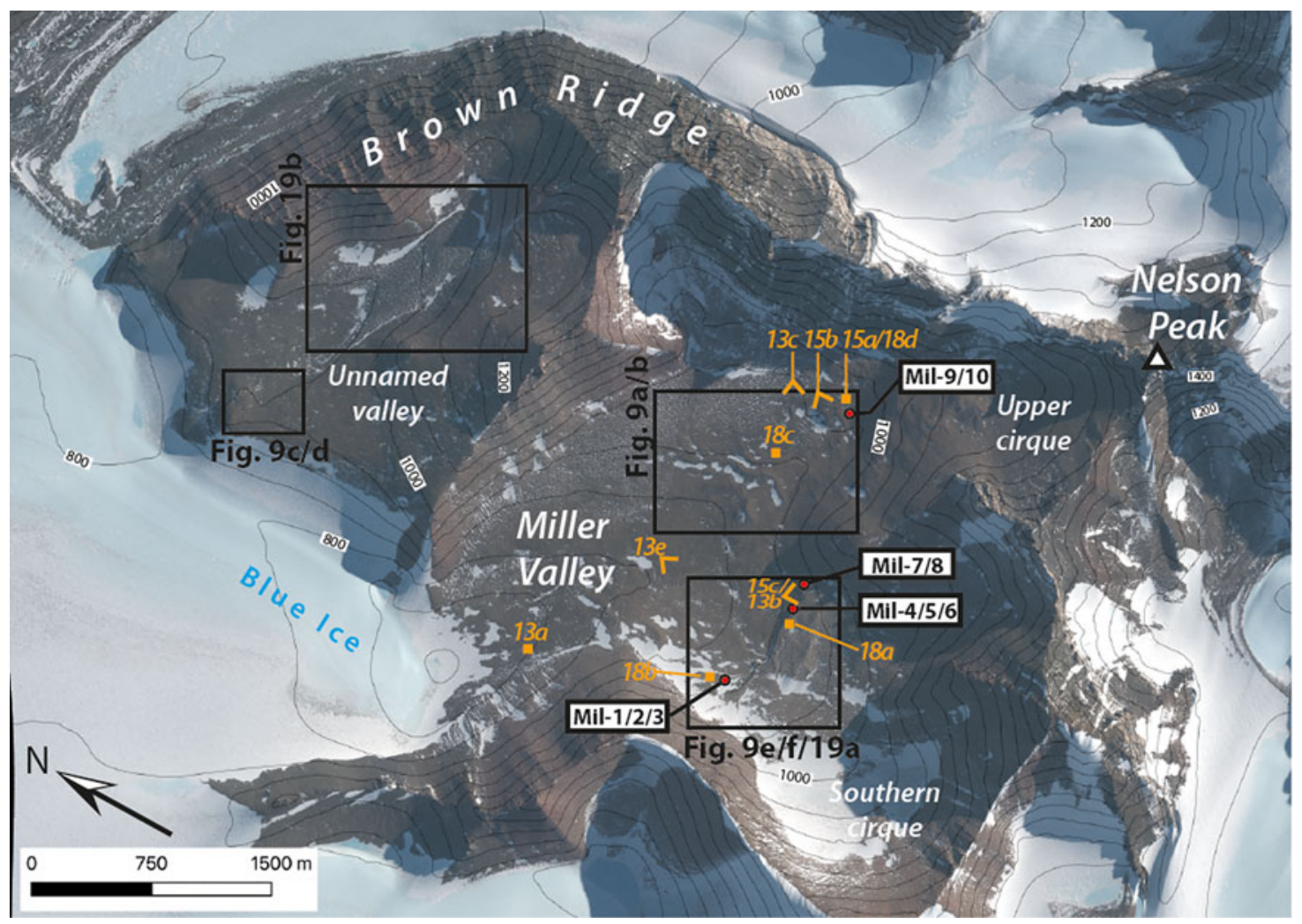

Fig. 3. Overview satellite image of the Miller Valley area showing the main features mentioned in the text and the locations of cosmogenic nuclide samples. Insets denote locations of panels in Figs 9 \& 19. Orange annotations indicate locations (squares) and directions (chevrons open in direction of view) of field photographs in Figs 13, 15 \& 18 (satellite imagery - WorldView3 $30 \mathrm{~cm}$ resolution - C2018 DigitalGlobe, Inc., a Maxar company). Contours (50 m intervals) extracted from Reference Elevation Model of Antarctica $8 \mathrm{~m}$ digital elevation model (Howat et al. 2019).

potential geomorphic record contained within these valleys and motivated subsequent mapping. $\mathrm{CHV}$ and SHV were not visited. Preliminary geomorphological mapping was undertaken from available aerial photographs and commercial satellite imagery (WorldView3 - $30 \mathrm{~cm}$ resolution; CDigitalGlobe, Inc., a Maxar company) georeferenced to the newly available Reference Elevation Model of Antarctica (REMA) $8 \mathrm{~m}$ digital elevation model (DEM) of Howat et al. (2019). The higher-resolution $2 \mathrm{~m}$ REMA DEM was used to aid mapping of features; however, its spatial coverage within areas of high relief such as the Neptune Range is incomplete and thus it was not used for georeferencing. We endeavoured to map all glacial landforms; however, in some areas, particularly heavily shaded areas, we do not have sufficient information to state that an absence of mapped landforms equates to no landforms being present. The aforementioned fieldwork provided basic field observations and photographs that were used to aid identification and interpretation of relevant features. However, it did not provide time for sedimentological investigations and geophysical equipment was not available.

Schmidt et al. (1978) noted erratics up to $1000 \mathrm{~m}$ above present-day ice and inferred that they were deposited by an ice sheet with a broadly similar configuration to present. Sampling for cosmogenic nuclide analysis $\left({ }^{10} \mathrm{Be}\right.$ and ${ }^{26} \mathrm{Al}$ ) was undertaken opportunistically during a wider sampling campaign (2009-2010) that aimed to constrain the thinning history of the last ice-sheet expansion in the Pensacola Mountains (Bentley et al. 2017). Samples were collected from two locations (Figs 2 \& 3). First, in Miller Valley, ten samples were collected from distinct depositional features or from boulders located on a drift sheet surface to provide preliminary constraints on the geomorphological record (Fig. 5). Second, a further eight samples came from the crest of Elliot Ridge and are presented here as they provide some constraint on the wider ice-sheet history. The samples from Elliot Ridge consist of five erratic clasts and three bedrock samples (Fig. 5). Samples were taken whole or sampled from larger boulders and bedrock with a hammer and chisel. Topographical shielding was measured using an Abney level and compass. Sample location information is presented in Table I.

Whole-rock samples were crushed and sieved to obtain the $250-710 \mu \mathrm{m}$ fraction. Quartz purification and $\mathrm{Be} / \mathrm{Al}$ extraction were undertaken at the University of Edinburgh's Cosmogenic Nuclide Laboratory following 


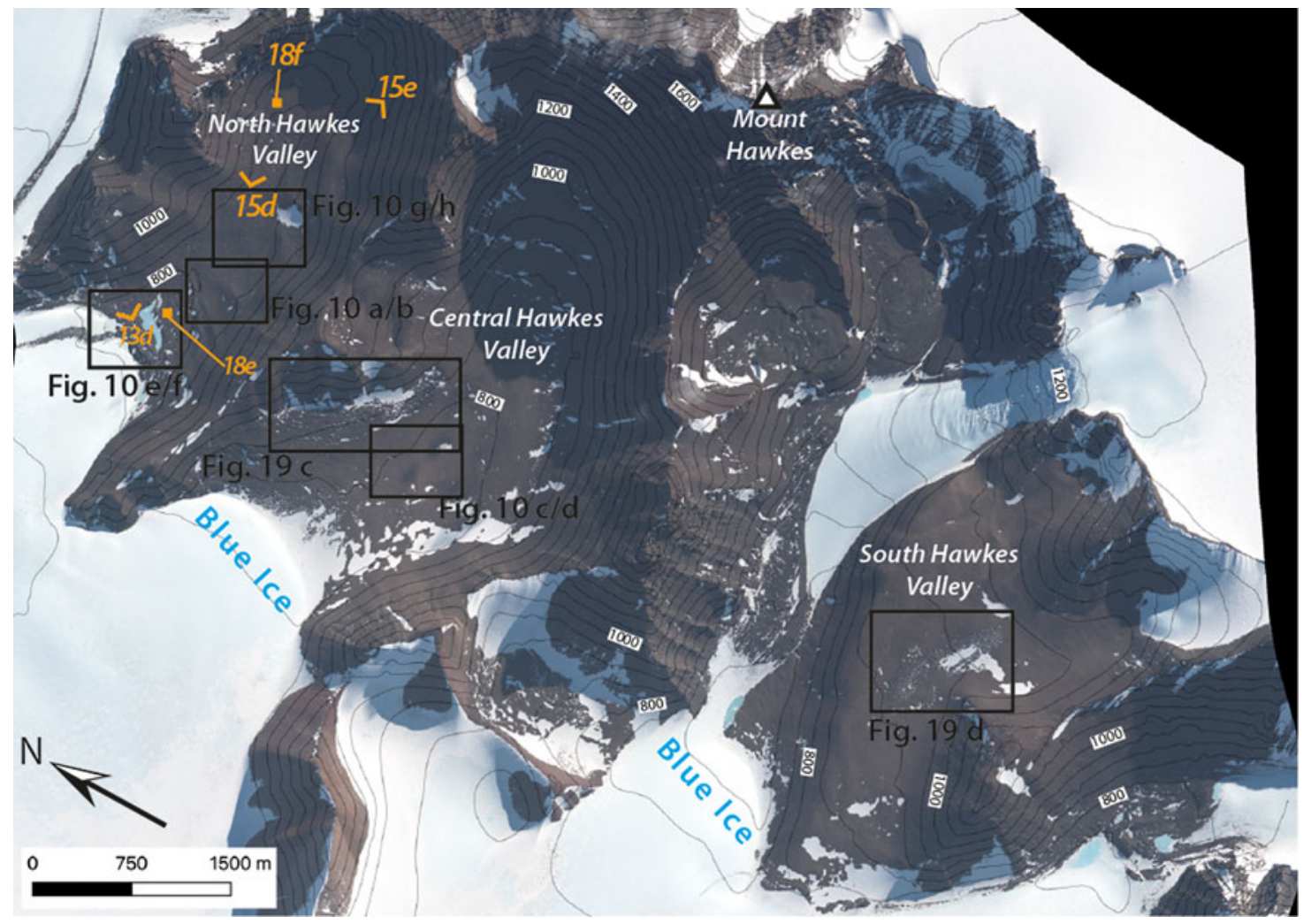

Fig. 4. Overview satellite image of the Hawkes Valleys area showing the main features mentioned in the text. Insets denote locations of panels in Figs 9 \& 19. Orange annotations indicate locations (squares) and directions (chevrons open in direction of view) of field photographs in Figs 13, 15 \& 18 (satellite imagery - WorldView3 $30 \mathrm{~cm}$ resolution - (C2018 DigitalGlobe, Inc., a Maxar company). Contours (50 m intervals) extracted from Reference Elevation Model of Antarctica $8 \mathrm{~m}$ digital elevation model (Howat et al. 2019).

established methods (cf. Kohl \& Nishiizumi 1992). ${ }^{10} \mathrm{Be} /{ }^{9} \mathrm{Be}$ and ${ }^{26} \mathrm{Al} /{ }^{27} \mathrm{Al}$ ratios were measured at the Scottish Universities Environmental Research Centre (SUERC) Accelerator Mass Spectrometry (AMS) Laboratory. Measurements are normalized to the NIST SRM-4325 Be standard material with a nominal ${ }^{10} \mathrm{Be} /{ }^{9} \mathrm{Be}$ of $2.79 \times 10^{-11}$ and the Purdue Z92-0222 Al standard material with a nominal ${ }^{26} \mathrm{Al} /{ }^{27} \mathrm{Al}$ of $4.11 \times 10^{-11}$. Be process blanks and samples were spiked with $\sim 250 \mu \mathrm{g}$ ${ }^{9}$ Be carrier (Scharlau Be carrier, $1000 \mathrm{mg} \mathrm{l}^{-1}$, density $1.02 \mathrm{~g} \mathrm{ml}^{-1}$ ). Al blanks were spiked with $\sim 1.5 \mathrm{mg}$ ${ }^{27} \mathrm{Al}$ carrier (Fischer $\mathrm{Al}$ carrier, $1000 \mathrm{ppm}$ ) and samples were spiked with up to $\sim 1.5 \mathrm{mg}{ }^{27} \mathrm{Al}$ carrier (the latter depending on the native $\mathrm{Al}$ content of the sample). Blanks range from $1.01 \times 10^{-14}$ to $3.04 \times 10^{-14}\left[{ }^{10} \mathrm{Be} /{ }^{9} \mathrm{Be}\right]$ and from $1.01 \times 10^{-13}$ to $3.80 \times 10^{-14}\left[{ }^{26} \mathrm{Al} /{ }^{27} \mathrm{Al}\right]$ (Tables I \& II). Given the large measured concentrations, our results and interpretation are insensitive to blank corrections. Concentrations (Tables I \& II) are corrected for process blanks; uncertainties include propagated AMS sample/lab blank uncertainty and a $2 \%$ carrier mass uncertainty.

Apparent exposure ages $\left({ }^{10} \mathrm{Be}\right.$ and $\left.{ }^{26} \mathrm{Al}\right)$ were calculated online using the default production rate data-set and Lifton-Sato-Dunai (LSDn) scaling (Lifton et al. 2014) within the exposure age calculator formerly known as the CRONUS-Earth online exposure age calculator, version 3 (https://sites.google.com/a/bgc.org/v3docs). Two-isotope plots were produced using iceTEA (Jones et al. 2019). For brevity, only ${ }^{10} \mathrm{Be}$ apparent exposure ages are quoted in the discussion. All apparent exposure ages and production rate-normalized ${ }^{26} \mathrm{Al} /{ }^{10} \mathrm{Be}$ ratios are presented in Table III. Ages were calculated assuming zero erosion and should thus be considered as minimum ages.

\section{Interpretation of mapped geomorphological features}

We first present our initial observations and interpretations of landforms in the Neptune Valleys before presenting the results of the preliminary geochronological analyses.

\section{Large-scale bedrock (geo)morphology}

The highest points on the Washington Escarpment crest, such as Mount Hawkes, Gambacorta Peak and Nelson Peak, have alpine forms with pyramidal peaks and intervening arêtes (Fig. 2). Lower sections of the escarpment are generally overridden by ice from the 

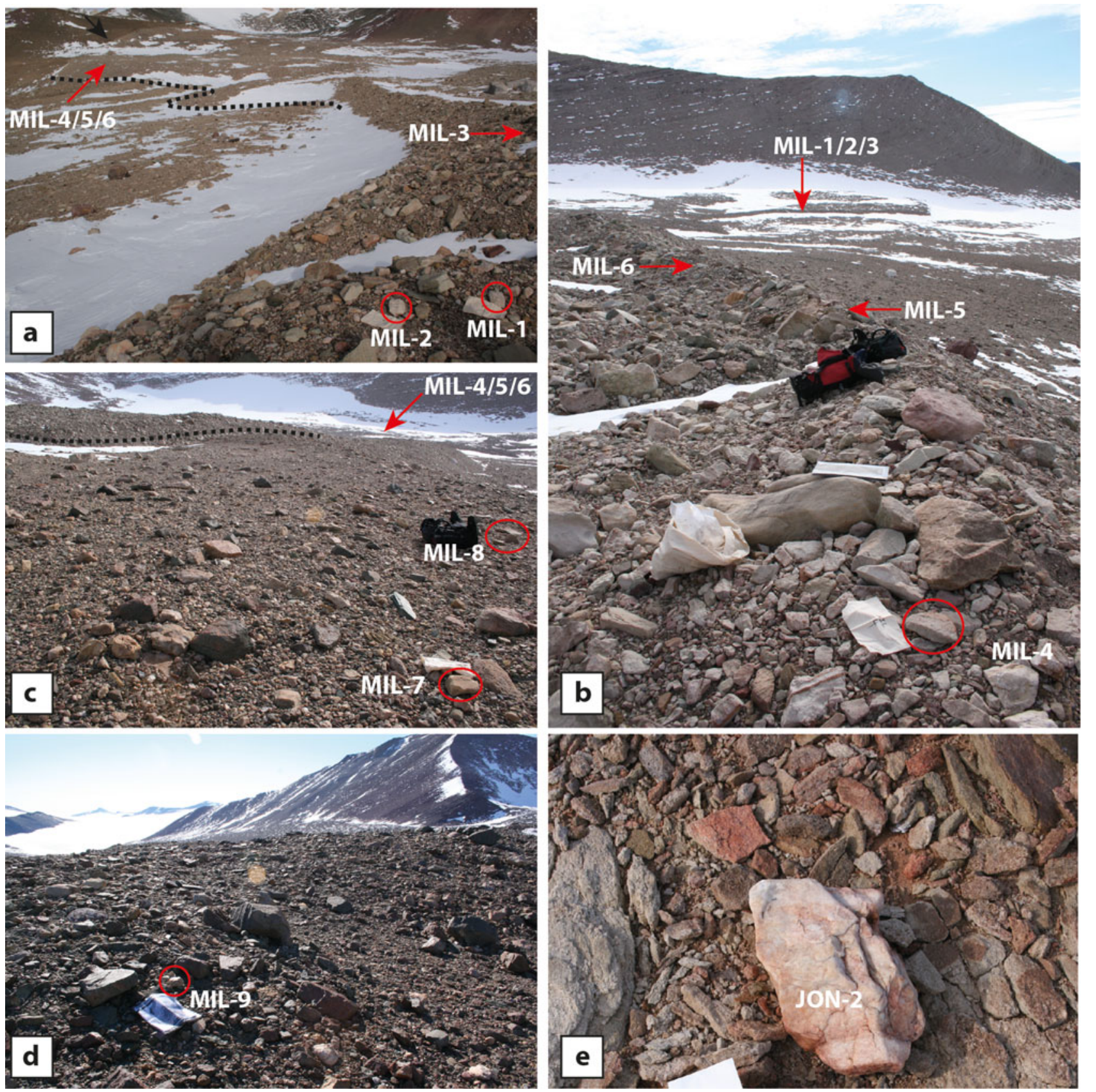

Fig. 5. Field photographs showing the context of selected cosmogenic nuclide samples from Miller Valley (a.-d.) and Elliot Ridge (e.). a. Looking along the frontal slope (dashed line) of the large discrete debris accumulation (DDA) in Miller Valley from location of MIL-1/2/3. Location of MIL-4/5/6 is arrowed. b. Location of MIL-4/5/6 on the crest of the DDA, view is back towards the location of MIL-1/2/3 (arrowed). c. Looking back from the location of MIL-7/8, on an older moraine bench. Note crosscutting relationship of the DDA denoted by the dashed line. Also note the increased weathering compared to clasts in panels a. and $\mathbf{c}$. Location of MIL-4/5/6 is arrowed. d. Location of sample MIL-9 (MIL-10 just out of view to the right). Note the increased degree of weathering of clasts. e. Sample JON-2 on the crest of Elliot Ridge. Note the distinct difference in appearance compared to the local bedrock.

Iroquois Plateau, but in places where they are not, a more subdued, potentially ice-smoothed topography can be observed (Fig. 6a), although this contrast may be controlled to some degree by lithology. Further to the west, away from the escarpment crest, ridges and peaks get progressively lower in altitude and are characterized by smooth topography and rectilinear slopes. One of the westernmost ridges (Elliot Ridge; Fig. 2) was also traversed on foot and displays large-scale ice smoothing where it fringes Roderick Valley (Fig. 6b \& c). However, it is also noted that bedrock on the crest of this ridge has features such as cavernous weathering, potentially 
Table I. Sample location, ${ }^{10} \mathrm{Be}$ chemistry and accelerator mass spectrometry data.

\begin{tabular}{|c|c|c|c|c|c|c|c|c|c|c|c|c|c|c|}
\hline Sample & Location & $\begin{array}{l}\text { Latitude } \\
\text { (DD) }\end{array}$ & $\begin{array}{l}\text { Longitude } \\
\text { (DD) }\end{array}$ & $\begin{array}{l}\text { Elevation } \\
\text { (m) }\end{array}$ & $\begin{array}{l}\text { Thickness } \\
(\mathrm{cm})\end{array}$ & Shielding & $\begin{array}{l}\text { Quartz mass } \\
(\mathrm{g})\end{array}$ & $\begin{array}{l}\text { Density-adjusted } \\
\text { Be spike }(\mu \mathrm{g})^{a}\end{array}$ & $\begin{array}{c}{ }^{10} \mathrm{Be} /{ }^{9} \mathrm{Be} \\
\text { ratio }^{b}\end{array}$ & $\pm 1 \sigma$ & $\begin{array}{c}\text { Blank } \\
{ }^{10} \mathrm{Be} /^{9} \mathrm{Be}^{c}\end{array}$ & $\pm 1 \sigma$ & $\begin{array}{c}{ }^{10} \mathrm{Be} \\
\text { concentration }\end{array}$ & $\pm 1 \sigma$ \\
\hline MIL-1 & Miller Valley & -83.6561 & -55.2681 & 899 & 3.5 & 0.991 & 26.3817 & 0.2475 & $2.01 \mathrm{E}-12$ & $1.81 \mathrm{E}-14$ & $1.19 \mathrm{E}-14$ & $1.74 \mathrm{E}-15$ & $1.25 \mathrm{E}+06$ & $2.77 \mathrm{E}+04$ \\
\hline MIL-2 & Miller Valley & -83.6561 & -55.2681 & 899 & 3.0 & 0.991 & 31.0829 & 0.2479 & $5.60 \mathrm{E}-12$ & $5.36 \mathrm{E}-14$ & $1.19 \mathrm{E}-14$ & $1.74 \mathrm{E}-15$ & $2.98 \mathrm{E}+06$ & $6.62 \mathrm{E}+04$ \\
\hline MIL-3 & Miller Valley & -83.6563 & -55.2683 & 927 & 5.0 & 0.991 & 29.8974 & 0.2481 & $3.52 \mathrm{E}-12$ & $3.49 \mathrm{E}-14$ & $2.06 \mathrm{E}-14$ & $1.93 \mathrm{E}-15$ & $1.94 \mathrm{E}+06$ & $4.36 \mathrm{E}+04$ \\
\hline MIL-4 & Miller Valley & -83.6576 & -55.2227 & 957 & 5.0 & 0.995 & 28.6681 & 0.2429 & $4.47 \mathrm{E}-12$ & $4.10 \mathrm{E}-14$ & $1.19 \mathrm{E}-14$ & $1.74 \mathrm{E}-15$ & $2.52 \mathrm{E}+06$ & $5.57 \mathrm{E}+04$ \\
\hline MIL-5 & Miller Valley & -83.6576 & -55.2232 & 957 & 3.5 & 0.995 & 25.7173 & 0.2438 & $2.67 \mathrm{E}-12$ & $2.68 \mathrm{E}-14$ & $1.19 \mathrm{E}-14$ & $1.74 \mathrm{E}-15$ & $1.68 \mathrm{E}+06$ & $3.79 \mathrm{E}+04$ \\
\hline MIL-6 & Miller Valley & -83.6576 & -55.2242 & 957 & 3.0 & 0.995 & 29.1727 & 0.2509 & $2.50 \mathrm{E}-12$ & $2.82 \mathrm{E}-14$ & $2.06 \mathrm{E}-14$ & $1.93 \mathrm{E}-15$ & $1.43 \mathrm{E}+06$ & $3.30 \mathrm{E}+04$ \\
\hline MIL-7 & Miller Valley & -83.6574 & -55.2093 & 962 & 3.5 & 0.993 & 26.4071 & 0.2433 & 2.09E-11 & $1.77 \mathrm{E}-13$ & $1.19 \mathrm{E}-14$ & $1.74 \mathrm{E}-15$ & $1.29 \mathrm{E}+07$ & $2.79 \mathrm{E}+05$ \\
\hline MIL-8 & Miller Valley & -83.6574 & -55.2096 & 962 & 5.5 & 0.993 & 28.4397 & 0.2497 & $1.88 \mathrm{E}-11$ & 7.17E-14 & 3.04E-14 & $2.08 \mathrm{E}-15$ & $1.10 \mathrm{E}+07$ & $2.25 \mathrm{E}+05$ \\
\hline MIL-9 & Miller Valley & -83.6556 & -55.1214 & 1000 & 5.0 & 0.993 & 28.3357 & 0.2379 & $2.49 \mathrm{E}-11$ & $2.32 \mathrm{E}-13$ & $1.01 \mathrm{E}-14$ & $1.48 \mathrm{E}-15$ & $1.39 \mathrm{E}+07$ & $3.08 \mathrm{E}+05$ \\
\hline MIL-10 & Miller Valley & -83.6555 & -55.1216 & 1000 & 5.0 & 0.993 & 31.8700 & 0.2526 & $3.16 \mathrm{E}-11$ & $2.98 \mathrm{E}-13$ & $1.01 \mathrm{E}-14$ & $1.48 \mathrm{E}-15$ & $1.68 \mathrm{E}+07$ & $3.71 \mathrm{E}+05$ \\
\hline JON-1 & Elliot Ridge & -83.9729 & -57.2544 & 1427 & 5.0 & 1.000 & 30.0250 & 0.2398 & $5.12 \mathrm{E}-11$ & 4.64E-13 & $1.01 \mathrm{E}-14$ & $1.48 \mathrm{E}-15$ & $2.73 E+07$ & $6.00 \mathrm{E}+05$ \\
\hline JON-2 & Elliot Ridge & -83.9727 & -57.2566 & 1418 & 5.0 & 1.000 & 28.4289 & 0.2393 & 5.47E-11 & 4.69E-13 & $1.01 \mathrm{E}-14$ & $1.48 \mathrm{E}-15$ & $3.08 \mathrm{E}+07$ & $6.70 \mathrm{E}+05$ \\
\hline JON-3B & Elliot Ridge & -83.9734 & -57.2538 & 1425 & 3.5 & 1.000 & 27.5562 & 0.2486 & 4.33E-11 & $3.22 \mathrm{E}-13$ & $2.06 \mathrm{E}-14$ & $1.93 \mathrm{E}-15$ & $2.61 \mathrm{E}+07$ & $5.57 \mathrm{E}+05$ \\
\hline JON-5 & Elliot Ridge & -83.9842 & -57.2145 & 1363 & 5.0 & 1.000 & 28.1456 & 0.2501 & $4.35 \mathrm{E}-11$ & $1.25 \mathrm{E}-13$ & $2.06 \mathrm{E}-14$ & $1.93 \mathrm{E}-15$ & $2.58 \mathrm{E}+07$ & $5.21 \mathrm{E}+05$ \\
\hline JON-6B & Elliot Ridge & -83.9843 & -57.2146 & 1363 & 5.0 & 1.000 & 31.5459 & 0.2494 & $5.24 \mathrm{E}-11$ & $1.61 \mathrm{E}-13$ & $2.06 \mathrm{E}-14$ & $1.93 \mathrm{E}-15$ & $2.77 \mathrm{E}+07$ & $5.60 \mathrm{E}+05$ \\
\hline JON-7B & Elliot Ridge & -83.6301 & -57.1666 & 1252 & 4.0 & 1.000 & 25.8391 & 0.2492 & $3.19 \mathrm{E}-11$ & $2.14 \mathrm{E}-13$ & $2.06 \mathrm{E}-14$ & $1.93 \mathrm{E}-15$ & $2.05 E+07$ & $4.33 \mathrm{E}+05$ \\
\hline JON-8 & Elliot Ridge & -83.9629 & -57.1661 & 1240 & 6.0 & 1.000 & 25.3044 & 0.2311 & $3.94 \mathrm{E}-11$ & 3.63E-13 & $1.01 \mathrm{E}-14$ & $1.48 \mathrm{E}-15$ & $2.40 \mathrm{E}+07$ & $5.29 \mathrm{E}+05$ \\
\hline JON-9 & Elliot Ridge & -83.9602 & -57.1650 & 1168 & 3.0 & 0.997 & 28.2251 & 0.2488 & $2.55 \mathrm{E}-11$ & $1.75 \mathrm{E}-13$ & $2.06 \mathrm{E}-14$ & $1.93 \mathrm{E}-15$ & $1.50 \mathrm{E}+07$ & $3.17 \mathrm{E}+05$ \\
\hline
\end{tabular}

${ }^{a}$ Samples spiked with Scharlau Be carrier (lot \#10843401), $1000 \mathrm{mg} \mathrm{l}^{-1}$, density $1.02 \mathrm{~g} \mathrm{ml}^{-1}$.

${ }^{b}$ Measured ${ }^{10} \mathrm{Be} /{ }^{9} \mathrm{Be}$ accelerator mass spectrometry ratios normalized to NIST SRM-4325 Be standard material with a nominal ${ }^{10} \mathrm{Be} /{ }^{9} \mathrm{Be}$ of $2.79 \times 10^{-11}$.

${ }^{c}$ Density-adjusted carrier additions to blanks ranged from 0.2364 to $0.2497 \mu \mathrm{g}$.

$\mathrm{DD}=$ decimal degrees 
Table II. ${ }^{26} \mathrm{Al}$ chemistry and accelerator mass spectrometry data.

\begin{tabular}{|c|c|c|c|c|c|c|c|c|c|}
\hline Sample & Location & $\begin{array}{l}{ }^{27} \mathrm{Al} \text { spike } \\
(\mathrm{mg})^{a}\end{array}$ & $\begin{array}{c}\text { Total }{ }^{27} \mathrm{Al} \text { content } \\
\text { (natural and spike) } \\
(\mathrm{mg})\end{array}$ & $\begin{array}{c}{ }^{26} \mathrm{Al} /{ }^{27} \mathrm{Al} \\
\text { ratio }\end{array}$ & $\pm 1 \sigma$ & $\begin{array}{c}\text { Blank } \\
{ }^{26} \mathrm{Al} /{ }^{27} \mathrm{Al}\end{array}$ & $\pm 1 \sigma$ & $\begin{array}{c}{ }^{26} \mathrm{Al} \\
\text { concentration }\end{array}$ & $\pm 1 \sigma$ \\
\hline MIL-1 & Miller Valley & 1.4937 & 6.7516 & $6.60 \mathrm{E}-13$ & $1.85 \mathrm{E}-14$ & $2.97 \mathrm{E}-14$ & $1.15 \mathrm{E}-14$ & $3.73 \mathrm{E}+06$ & $2.17 \mathrm{E}+05$ \\
\hline MIL-2 & Miller Valley & 1.4937 & 5.3279 & 3.39E-12 & $6.93 \mathrm{E}-14$ & 2.97E-14 & $1.15 \mathrm{E}-14$ & $1.29 \mathrm{E}+07$ & $7.00 \mathrm{E}+05$ \\
\hline MIL-3 & Miller Valley & - & - & - & - & - & - & - & - \\
\hline MIL-4 & Miller Valley & 1.4937 & 4.6515 & $2.37 \mathrm{E}-12$ & $5.90 \mathrm{E}-14$ & $2.97 \mathrm{E}-14$ & $1.15 \mathrm{E}-14$ & $8.54 \mathrm{E}+06$ & $4.79 \mathrm{E}+05$ \\
\hline MIL-5 & Miller Valley & 1.4937 & 6.4924 & $9.52 \mathrm{E}-13$ & $2.47 \mathrm{E}-14$ & $2.97 \mathrm{E}-14$ & $1.15 \mathrm{E}-14$ & $5.32 \mathrm{E}+06$ & $3.02 \mathrm{E}+05$ \\
\hline MIL-6 & Miller Valley & - & - & - & - & - & - & - & - \\
\hline MIL-7 & Miller Valley & 1.4937 & 3.9925 & $1.75 \mathrm{E}-11$ & $4.20 \mathrm{E}-13$ & $2.97 \mathrm{E}-14$ & $1.15 \mathrm{E}-14$ & $5.92 \mathrm{E}+07$ & $3.28 \mathrm{E}+06$ \\
\hline MIL-8 & Miller Valley & - & - & - & - & - & - & - & - \\
\hline MIL-9 & Miller Valley & 1.6355 & 5.3721 & $1.57 \mathrm{E}-11$ & $3.36 \mathrm{E}-13$ & $3.80 \mathrm{E}-14$ & 4.99E-15 & $6.65 \mathrm{E}+07$ & $3.62 \mathrm{E}+06$ \\
\hline MIL-10 & Miller Valley & 1.6355 & 4.5181 & $2.44 \mathrm{E}-11$ & $5.06 \mathrm{E}-13$ & $3.80 \mathrm{E}-14$ & 4.99E-15 & $7.72 \mathrm{E}+07$ & $4.18 \mathrm{E}+06$ \\
\hline JON-1 & Elliot Ridge & 1.6355 & 4.8680 & $2.96 \mathrm{E}-11$ & $3.12 \mathrm{E}-13$ & $3.80 \mathrm{E}-14$ & 4.99E-15 & $1.07 \mathrm{E}+08$ & $5.47 \mathrm{E}+06$ \\
\hline JON-2 & Elliot Ridge & 1.6355 & 3.5575 & $4.48 \mathrm{E}-11$ & $3.87 \mathrm{E}-13$ & $3.80 \mathrm{E}-14$ & 4.99E-15 & $1.25 \mathrm{E}+08$ & $6.35 \mathrm{E}+06$ \\
\hline JON-3B & Elliot Ridge & 1.5311 & 4.9067 & $2.68 \mathrm{E}-11$ & $3.55 \mathrm{E}-13$ & $1.01 \mathrm{E}-13$ & $2.08 \mathrm{E}-14$ & $1.06 \mathrm{E}+08$ & $5.50 \mathrm{E}+06$ \\
\hline JON-5 & Elliot Ridge & 1.5311 & 5.0320 & $2.71 \mathrm{E}-11$ & $3.26 \mathrm{E}-13$ & $1.01 \mathrm{E}-13$ & $2.08 \mathrm{E}-14$ & $1.08 \mathrm{E}+08$ & $5.57 \mathrm{E}+06$ \\
\hline JON-6B & Elliot Ridge & 1.5311 & 4.7017 & $3.25 \mathrm{E}-11$ & $4.94 \mathrm{E}-13$ & $1.01 \mathrm{E}-13$ & $2.08 \mathrm{E}-14$ & $1.08 \mathrm{E}+08$ & $5.64 \mathrm{E}+06$ \\
\hline JON-7B & Elliot Ridge & 1.5311 & 3.0571 & $3.40 \mathrm{E}-11$ & $4.50 \mathrm{E}-13$ & $1.01 \mathrm{E}-13$ & $2.08 \mathrm{E}-14$ & $8.96 \mathrm{E}+07$ & $4.64 \mathrm{E}+06$ \\
\hline JON-8 & Elliot Ridge & 1.6355 & 3.3741 & $3.29 \mathrm{E}-11$ & $3.45 \mathrm{E}-13$ & $3.80 \mathrm{E}-14$ & 4.99E-15 & $9.78 \mathrm{E}+07$ & $5.00 \mathrm{E}+06$ \\
\hline JON-9 & Elliot Ridge & 1.5311 & 4.7297 & $1.91 \mathrm{E}-11$ & $2.91 \mathrm{E}-13$ & $1.01 \mathrm{E}-13$ & $2.08 \mathrm{E}-14$ & $7.13 \mathrm{E}+07$ & $3.73 \mathrm{E}+06$ \\
\hline
\end{tabular}

${ }^{a}$ Samples spiked with Fischer Al carrier, 1000 ppm.

${ }^{b}$ Measured ${ }^{26} \mathrm{Al} /{ }^{27} \mathrm{Al}$ accelerator mass spectrometry ratios normalized to Purdue Z92-0222 $\mathrm{Al}$ standard material with a nominal ${ }^{26} \mathrm{Al} /{ }^{27} \mathrm{Al}$ of $4.11 \times 10^{-11}$.

indicative of long-term erosion by wind or granular disaggregation (n.b. salt weathering is considered improbable given the location) (Fig. 6d-f).

\section{Geomorphology of the Neptune Valleys}

The Neptune Valleys contain a variety of geomorphological features relating to both past and ongoing processes
(Figs 7-10 \& Table IV). The main features relevant to the potential of these valleys as terrestrial archives of past environmental change are described here. As stated previously, the field time available prevented sedimentological observations from being made. Clearly, detailed investigation of any available sediment exposures or excavated pits, alongside geophysical techniques, would provide further insights into the stratigraphy and structure

Table III. Apparent exposure ages and production rate-normalized ${ }^{26} \mathrm{Al} /{ }^{10} \mathrm{Be}$ ratios of all samples from Miller Valley and Elliot Ridge. Italicized ratios plot below the erosion island (Fig. 12).

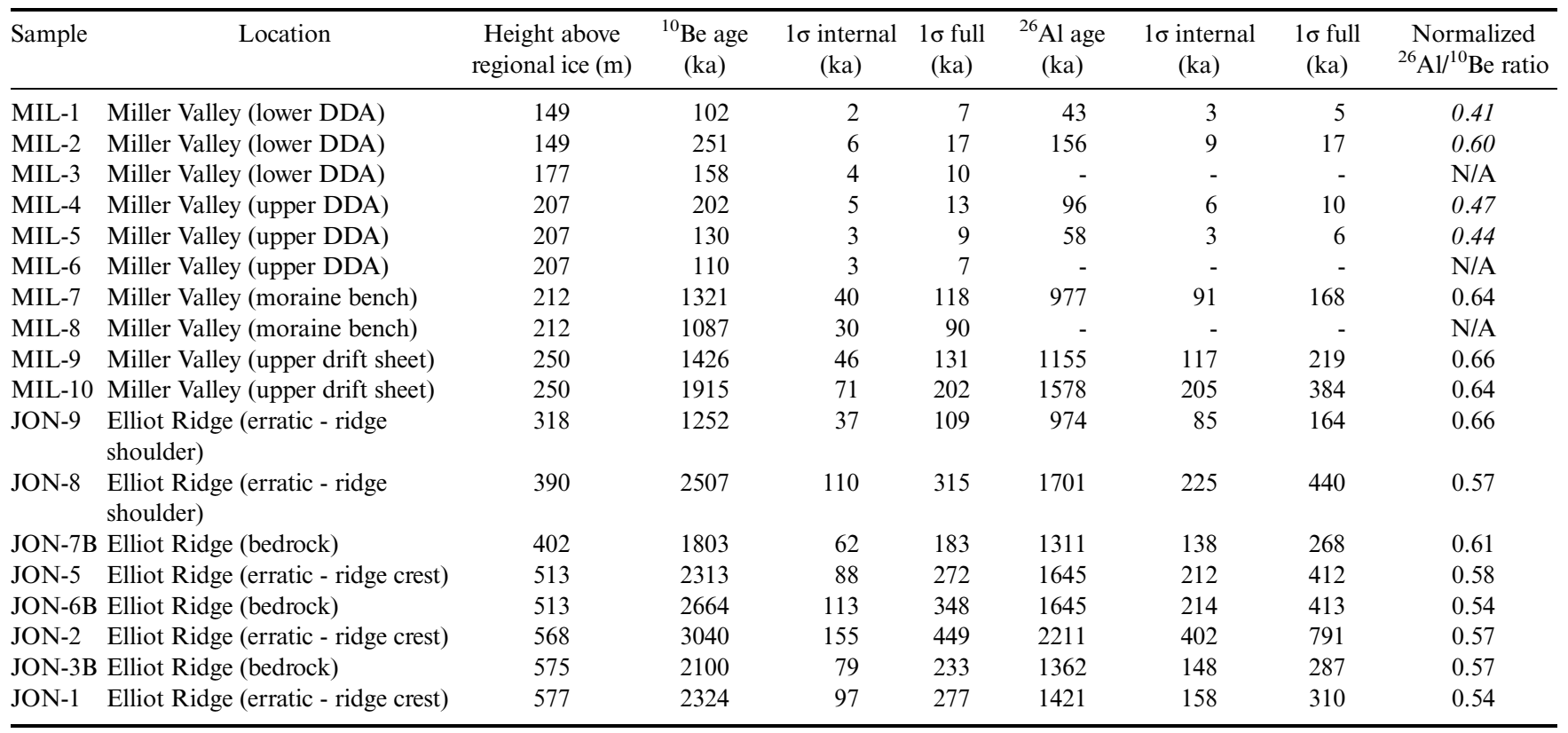

$\mathrm{DDA}=$ discrete debris accumulation. 

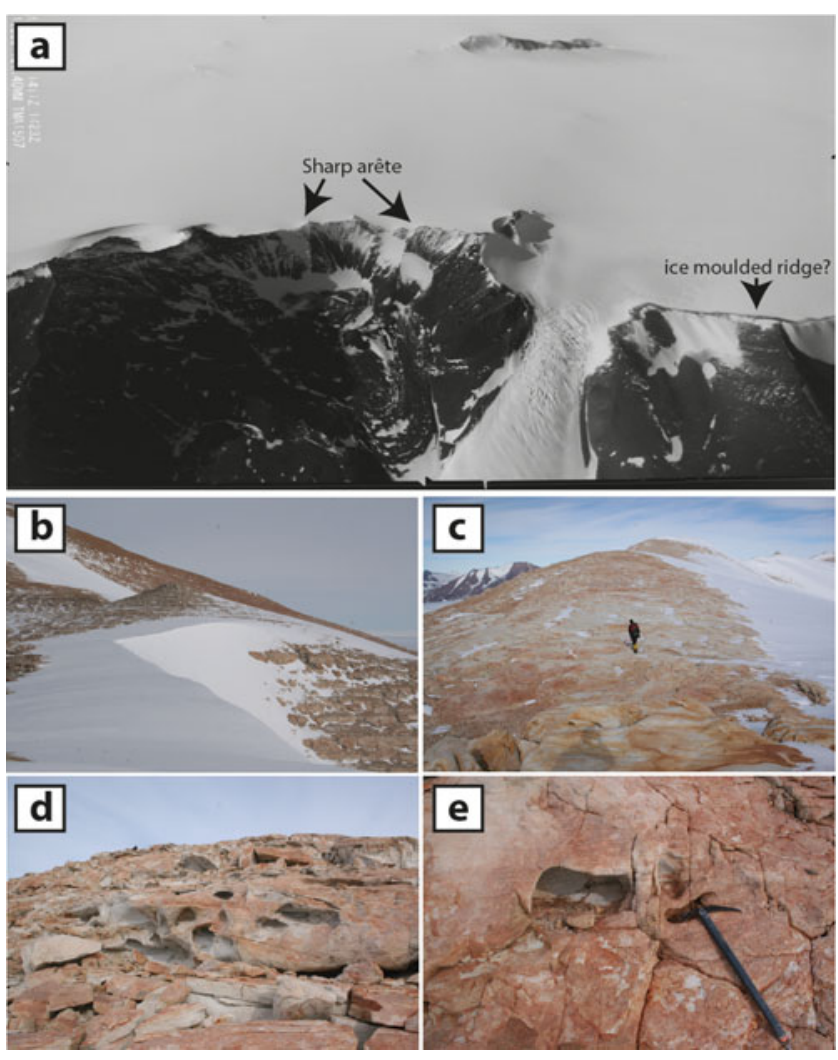

Fig. 6. a. Oblique aerial photograph (TMA1507 - L0176 -

18/12/64) showing the contrast in ridge morphology between the sharp arête extending from the summit of Mount Hawkes and the probable ice-moulded ridge on the other side of the glacial breach. Note the rock glacier in the cirque. b. \& c. Field photographs of bedrock morphology observed on the summit of Elliot Ridge showing potential large-scale ice smoothing, although the direction of flow is ambiguous. d. \& e. Examples of cavernous weathering observed on the ridge crest.

of the landforms and subsurface debris and ice (e.g. Hambrey \& Fitzsimons 2010). This information would allow further refinement, or rejection, of our proposed model of deposition devised from the observed landforms. It would also allow comparison to more detailed facies-based studies of depositional landforms associated with glaciers in the MDVs (e.g. Hambrey \& Fitzsimons 2010) As such, all process interpretations are made with this caveat in mind and should be considered hypotheses for testing rather than definitive statements.

Controlled moraines occur in numerous locations at lateral and frontal ice margins, and discrete accumulations of supraglacial debris are visible on the ice surfaces (e.g. Figs $7,8 \& 10 \mathrm{e} \& \mathrm{f}$ ). These deposits are distinctly linear and are found in association with sources of debris such as medial and lateral debris bands, free faces and debris-mantled slopes. Their surfaces are characterized by frozen water-filled depressions and debris mounds and cones that can be several metres high. Their positive relief is probably attributable to differential ablation, whereby the thick debris cover protects underlying ice from ablation (e.g. Dyke \& Evans 2003). These features are interpreted as controlled moraines, supraglacial debris accumulations that possess clear linearity due to inheritance from debris-rich ice folia (Rains \& Shaw 1981, Fitzsimons 2003, Evans 2009). Controlled moraine occurs where any one of a number of processes delivers debris to the glacier surface, which in this context may include net adfreezing, englacial thrusting, overriding and entrainment of existing deposits (apron entrainment, sensu Shaw 1977, Evans 1989) and rock fall from surrounding slopes (Swanger et al. 2011, Fitzsimons 2003, Evans 2009). Once substantially developed and detached from a receding glacier snout, controlled moraines are akin to ice-cored moraines (cf. Lukas et al. 2005), because ice constitutes the majority of relief in each ridge or mound. In certain areas of Antarctica, substantial areas of supraglacial moraine are inferred to be formed by sublimation-driven upward flow of debris-bearing ice and are termed 'blue ice moraines' (e.g. Altmaier et al. 2010). These features are consistent with the definition of controlled moraines. In this study setting we prefer the term 'controlled moraine' as it does not imply a dominant process (i.e. sublimation) responsible for the concentration of debris on the ice surface.

Moraine ridges and mounds are the most common features lying beyond modern glacier snouts and comprise curvilinear ridges and associated mounds (Figs 7-9 \& 10a $\& b)$. The ridges are tens to hundreds of metres long and range in height from $<1$ to $>5 \mathrm{~m}$. The sub-parallel orientation of the ridges with respect to present-day ice margins in most locations strongly suggests that these are latero-frontal ice-contact features associated with previously expanded ice. In the simplest terms they could be described as moraines indicative of ice-margin advance (s) and/or still-stands during episodes of retreat. Without data on the sedimentological assemblages associated with these ridges we cannot state with any certainty the specific process involved in their formation. Broad ridges have subdued relief, potentially reflecting wind deflation and/or more advanced stages of melt-out of buried ice. In some places these broad ridges are superimposed by narrower ridges of fresher appearance. Narrow ridges (especially those superimposed on others) may reflect differential melting of particularly debris-rich ice layers (cf. controlled moraines). Thus it is possible that many of these ridges, particularly the narrow and fresh examples, may remain ice cored; however, excavations would be required to confirm this. The contrast in ridge morphology, particularly evident in NHV, may also suggest multiple phases of ice advance and retreat, allowing for evolution of the ridge morphology with time. In many places the ridges are associated with mounds that are visually similar but lack their linearity. Sedimentological analysis could 


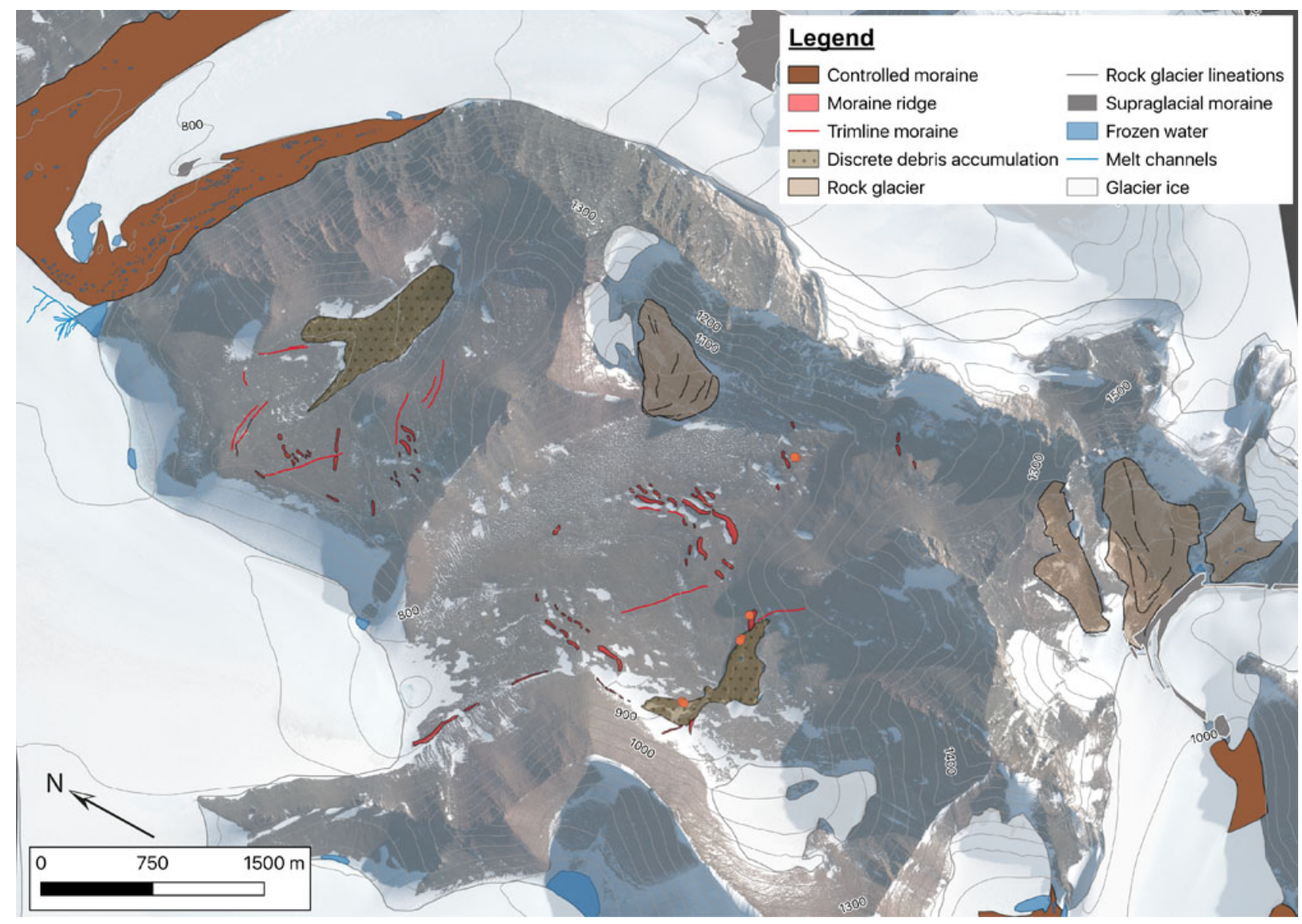

Fig. 7. Geomorphological map of the main features identified in the Miller Valley area (n.b. moraine mounds are not shown at this scale). Base imagery is WorldView3 $30 \mathrm{~cm}$ resolution - C2018 DigitalGlobe, Inc., a Maxar company.

confirm whether the ridges and mound share a common genesis.

Boulder-belt or trimline moraines are further curvilinear features associated with ridges and generally comprise coarser boulder-grade material but lack significant relief. The morphological association of these features with the curvilinear ridges suggests that they are related and hence are also interpreted as latero-frontal ice-contact features (Fig. 9c \& d), specifically boulder-belt or trimline moraines (Ó Cofaigh et al. 2003, Evans 2009; cf. 'drop moraines' of Atkins 2013). The differing morphology between these features is probably a product of spatial and/or temporal variations in debris supply via englacial transport. Low volumes of debris during glacier snout downwasting would result in features with little to no relief, particularly after ablation of any remnant ice. In this case these features could also be described as drift limits. In some places these features comprise a spread of boulders with a distinct transverse limit that is commonly associated with moraine ridges (e.g. Fig. 9c \& d). The spread of material may reflect time-transgressive deposition of material during glacier recession.
Circular depositional features are observed on the floor of NHV and CHV (Fig. 8) and comprise distinct circular features that are often characterized by darker and finer material and can form mounds $2-3 \mathrm{~m}$ in height (Fig. 10c \& d). In some places these features consist of a small circular ridge of material with the centre being similar in appearance to the material that makes up the majority of the valley floor. The deposits drape the valley bottom material, and in some cases also drape ridges. These features bear resemblance to circular moraine features (Ebert \& Kleman 2004) where circular to oval-shaped deposits of glacial debris are deposited from debris-rich ice blocks that melt out following downwasting to form mounds, sheets or rings. Their constituent material differs from the underlying substrate. It is noted that in some of the mapped features the material that comprises the features appears to be finer. Therefore, another possible mode of formation is accumulation of sediment in circular, water-filled depressions (observed in association with current debris accumulations) on the ice surface prior to downwasting, akin to small ice-walled lake plains (Clayton et al. 2008). 


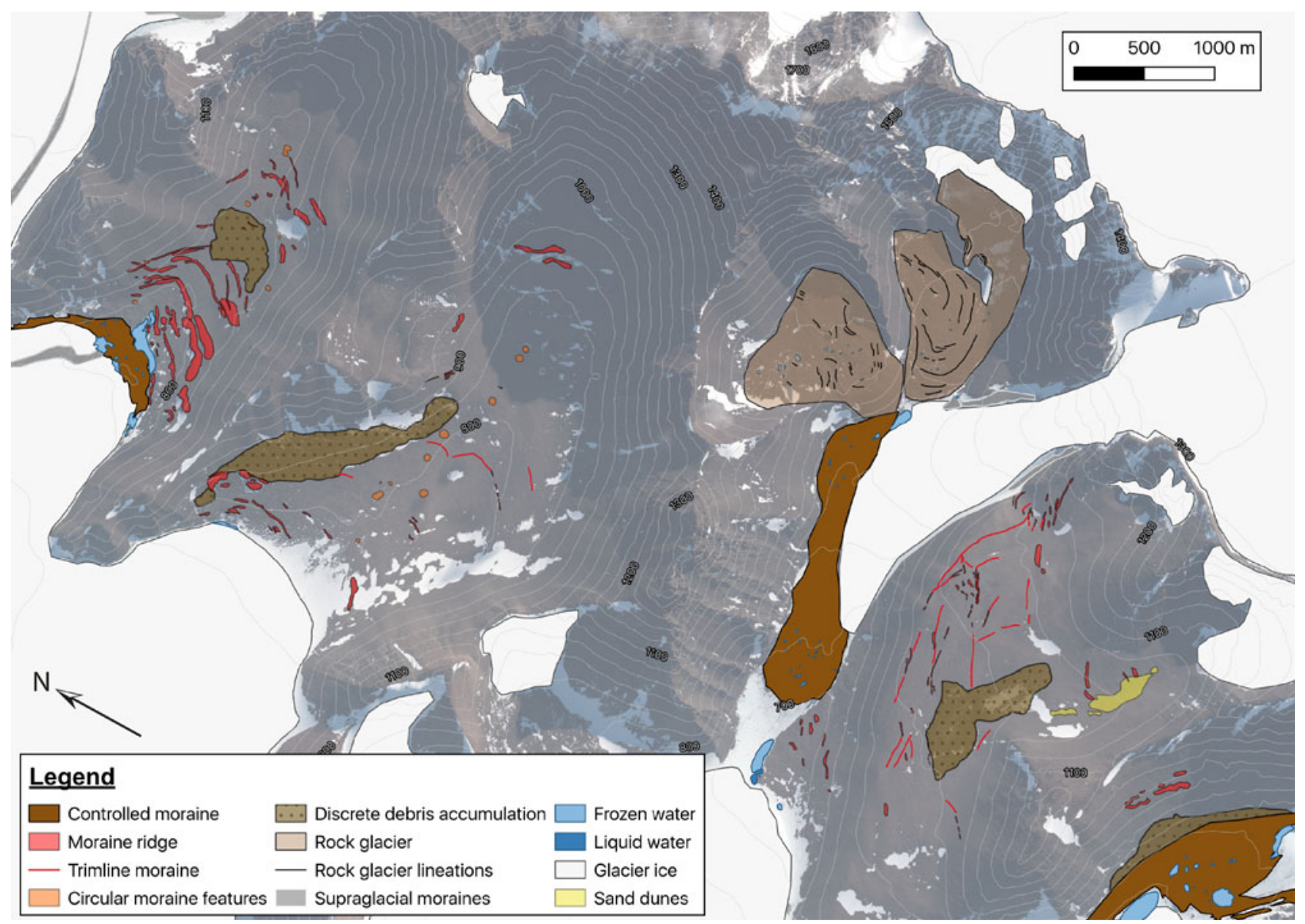

Fig. 8. Geomorphological map of the main features identified in the Hawkes Valleys area (n.b. moraine mounds and debris cones are not shown at this scale). Base imagery is WorldView3 $30 \mathrm{~cm}$ resolution - C2018 DigitalGlobe, Inc., a Maxar company.

While acknowledging that there may be a degree of equifinality, and without sedimentological data to inform a process interpretation, we use the term 'circular depositional feature' (CDF) as it does not imply a specific mode of formation. Nevertheless, these features are considered diagnostic of previously expanded ice with an englacial and/or supraglacial debris load.

Discrete debris accumulations are observed in several places in both Miller Valley and the Hawkes Valleys. They are extensive raised areas with positive relief of several metres and surfaces characterized by chaotic, often widely spaced hummocks and discontinuous curvilinear ridges in an otherwise polygonized terrain; the latter often constitute well-developed frost-sorted polygons with high centres and deep troughs (Figs 9e \& f \& $10 \mathrm{~g} \& \mathrm{~h}$ ). The presence of mounds and ridges on the surfaces (and in places forming the margins) of many of these areas indicates that they are related to the downwasting of formerly more expansive ice, with the mounds and ridges probably relating to controlled moraine construction. This interpretation is compatible with the probable origin of the polygons and their associated deep troughs and high-relief centres, which elsewhere have been regarded as diagnostic of the melt-out or sublimation of buried ice (Dyke \& Savelle 2000, Marchant et al. 2002). Given the pervasive cold temperatures at this latitude, it is probable that at least some of these features remain ice cored.

These features are generally associated with debris sources (cf. the areas of controlled moraine described above) and in some cases mirror the present-day ice margin, especially in NHV, where the pattern of the raised area of polygonized terrain is accordant with that of the active controlled moraines (Fig. 10e-h). Elsewhere the raised areas have no analogues on the modern ice surface and hence we interpret them as relict supraglacial debris accumulations on snouts that have become separated from receding ice margins during ice retreat/thinning. These were almost certainly initially created by the concentration of supraglacial debris, and the patchy nature of the linearity indicates controlled moraine construction. However, the predominant lack of linearity suggests that either the debris concentrations in the ice folia feeding the controlled ridges were low and/or a more evenly distributed debris cover was 


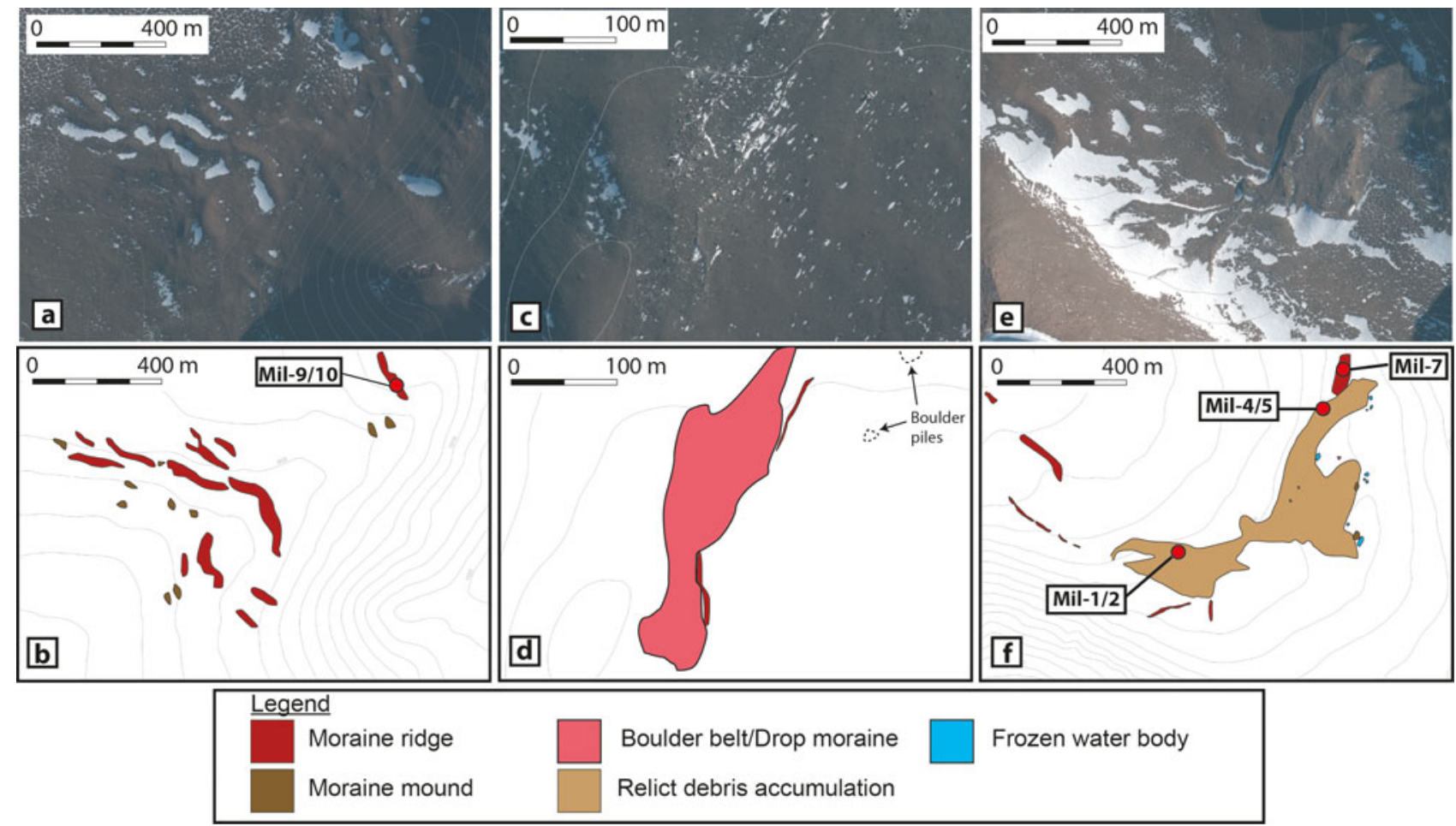

Fig. 9. Examples of geomorphological features mapped in Miller Valley. a. \& b. WorldView imagery and interpreted map of moraine ridges and mounds on the central valley floor. Location of cosmogenic nuclide samples MIL-9/10 is shown. c. \& d. Sharp moraine ridges and broad boulder-belt/drop moraine at the lower section of the unnamed valley floor (n.b. at this scale the drop moraine is shown as a polygon, shown as a line in Fig. 7). e. \& f. Discrete debris accumulation and moraine ridges in Miller Valley. Locations of cosmogenic nuclide samples MIL-1/2, $-4 / 5$ and -7 are shown.

created on the ice surface as it progressively sublimated. As we cannot infer the specific processes, we prefer the non-genetic term 'discrete debris accumulation' (DDA) (Whalley 2009) to describe these features and acknowledge that they may represent a process-form continuum. If our general interpretation is correct, then sedimentological analysis of undisturbed sections of these features would probably be consistent with origin as a sublimation till and the component lithologies should be represented in the present-day debris load of the relevant ice margin. Additionally, geophysical investigations could shed light on the presence of any surviving buried ice bodies.

Frost-sorted polygons characterize the unconsolidated materials of the valley floors, and the flatter surfaces on benches and valley sides are often characterized by frost-sorted polygons. In places, polygons grade into stripes on steeper slopes. The polygons take on a wide range of differing morphologies from well-connected troughs and high-centred polygons to incipient surface cracking with no observable positive relief. The morphology varies over short distances and in places the boundaries between areas of different polygon morphologies is sharp. The variety of morphologies suggests that there may be differing modes of formation (i.e. sublimation vs sand-wedging; cf. Marchant et al. 2002). Additionally, polygon morphology may reflect differences in the unconsolidated material in which they are formed and/or the length of time available for polygon formation (Dyke \& Savelle 2000). We did not systematically map polygon distribution due to uncertainties in classification from available imagery and lack of ground-truthing.

Rock glaciers are found within some cirques and hollows, and they consist of distinct lobate features that are sometimes observed with significant frontal snouts up to $>100 \mathrm{~m}$ high (Fig. 11). Their surfaces are characterized by inset sequences of curved ridges whose orientations often mirror the lobate frontal snout and are sometimes characterized by bands of coarser material. These multiple ridges predominantly give a sense of flow, but in one instance they are more chaotic (Fig. 11a). Nevertheless, their appearance qualifies them as rock glaciers or rock glacierized debris assemblages (Benn \& Evans 2010) whereby the term is used descriptively and non-genetically. Additionally, some of these rock glaciers in the Miller Valley area have polygonized surfaces potentially indicative of buried glacier ice; the deformation of polygons in these cases gives a sense of flow towards the lobate snout. Frozen 


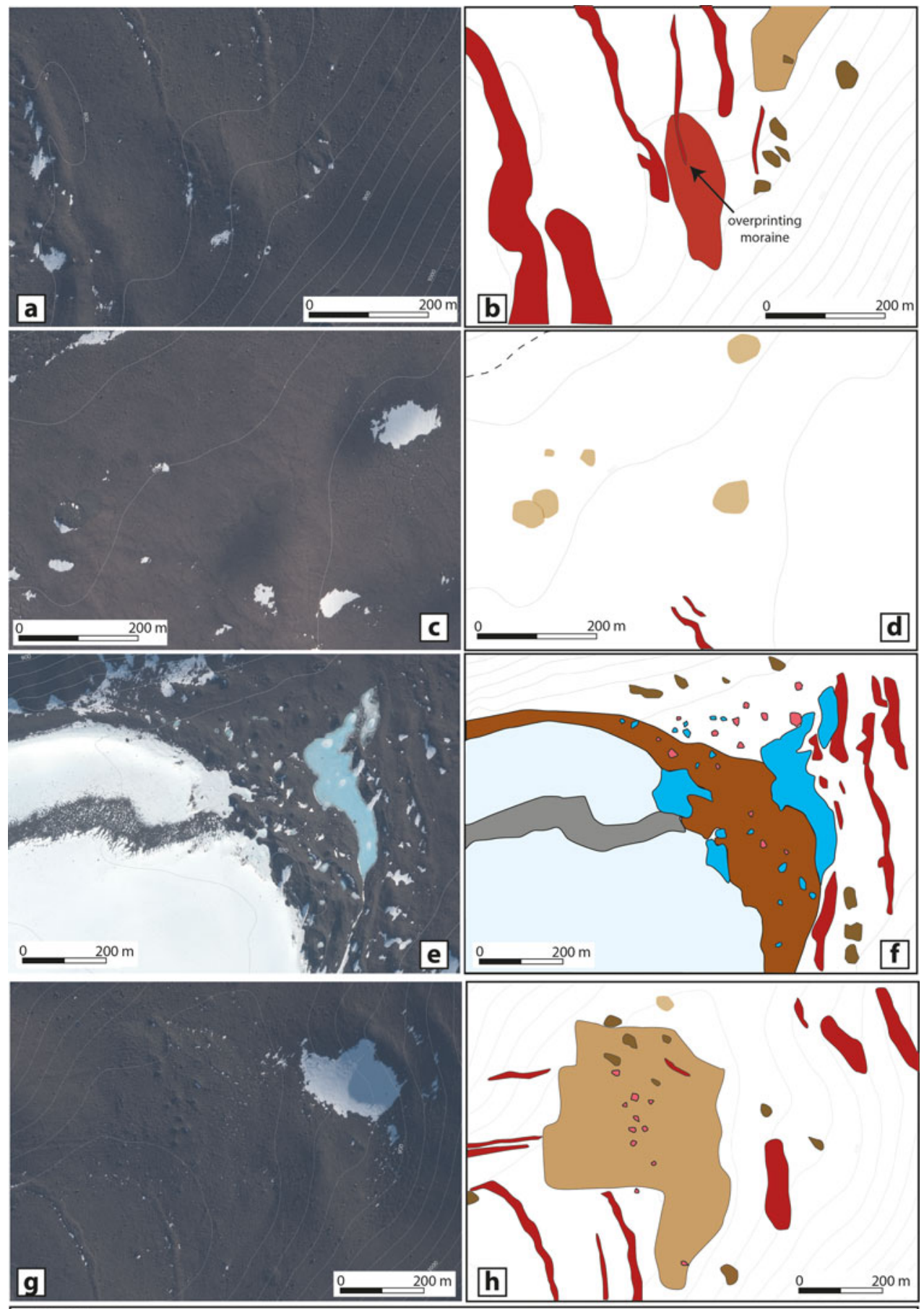

\begin{tabular}{|c|c|c|}
\hline \multicolumn{3}{|l|}{ Legend } \\
\hline Moraine ridge & Debris cone & Supraglacial debris \\
\hline Moraine mound & Controlled moraine & Frozen water body \\
\hline Circular moraine feature & Relict debris accumulation & Glacier ice/perennial snow \\
\hline
\end{tabular}

Fig. 10. Examples of geomorphological features mapped in the Hawkes Valleys. a. \& b. WorldView imagery and interpreted map of the series of moraine ridges and mounds on valley floor. Note the overprinting moraine and difference in moraine morphologies.

c. \& d. Circular moraine features on the floor of Central Hawkes Valley. e. \& f. Controlled moraine and associated debris cones and mounds at the ice margin in North Hawkes Valley. Note the frozen bodies of water and more distal moraine ridges. g. \& h. Discrete debris accumulation in North Hawkes Valley with moraine ridge, mounds and debris cones on its surface. Note the positive relief and polygonized surface of the feature compared to the nearby valley floor. Also note the broad similarity in appearance with the present controlled moraine at the ice margin. 
Table IV. Landform identification criteria.

\begin{tabular}{|c|c|c|}
\hline Landform & Morphology and appearance & Interpretation \\
\hline Moraine mounds & $\begin{array}{l}\text { Similar surficial appearance to moraine ridges and found in } \\
\text { close association. Lack linearity. Also observed on some } \\
\text { discrete debris accumulations }\end{array}$ & Mark approximate ice-marginal positions \\
\hline $\begin{array}{l}\text { Trimline moraines (cf. } \\
\text { boulder-belt or drop } \\
\text { moraines) }\end{array}$ & $\begin{array}{l}\text { Linear surface features with little to no relief. Can be } \\
\text { composed of notably coarser clasts than neighbouring } \\
\text { material. Often extend the trend of moraine ridges }\end{array}$ & Mark ice-marginal positions \\
\hline $\begin{array}{l}\text { Circular depositional } \\
\text { features }\end{array}$ & $\begin{array}{l}\text { Circular deposits } 10-50 \mathrm{~m} \text { in diameter, often of finer-grade } \\
\text { dark material. Can form ring-like structures on valley floors }\end{array}$ & $\begin{array}{l}\text { Either englacial sediment deposited during downwasting or } \\
\text { sediment infill of depression in ice surface. Potentially a } \\
\text { process-form continuum. Give minimum constraint on past } \\
\text { ice extent }\end{array}$ \\
\hline $\begin{array}{l}\text { Discrete debris } \\
\text { accumulations }\end{array}$ & $\begin{array}{l}\text { Positive relief features with polygonized surfaces (high } \\
\text { centres/deep troughs). Edges can be delimited by scarp slopes } \\
\text { several metres high. Mounds and ridges observed on some } \\
\text { examples. Morphologically disconnected from present ice } \\
\text { surface but can mirror former inferred ice extent }\end{array}$ & $\begin{array}{l}\text { Some are former areas of controlled moraine that became } \\
\text { separated from active ice during glacier retreat. Other } \\
\text { examples may have formed due to progressive accumulation } \\
\text { of englacial debris on the ice surface during downwasting. } \\
\text { Potentially ice cored }\end{array}$ \\
\hline Frost-sorted polygons & $\begin{array}{l}\text { Polygons observed in unconsolidated material on flatter } \\
\text { valley floors. Range of morphologies and differential levels of } \\
\text { maturation varying over short distances }\end{array}$ & $\begin{array}{l}\text { Range of morphology reflects different processes and/or } \\
\text { time available for formation }\end{array}$ \\
\hline Rock glaciers & $\begin{array}{l}\text { Lobate features observed in cirques. Surfaces exhibit } \\
\text { lineation, defined both by grade of material and positive } \\
\text { relief. Give sense of flow direction towards the lobate snout }\end{array}$ & Debris-covered/rock glaciers \\
\hline
\end{tabular}

ponds are often visible in circular depressions on the surfaces of these landforms and clean snow/ice is often, although not always, visible in the upper parts of the host cirques. Where ice is present upslope of these features their origins are likely to be from debris-covered glaciers. Note that the term 'viscous flow feature' has been proposed for such landforms by Marchant \& Head (2007), which we avoid here as it implies a genesis, whereas the term 'rock glacier', used in its purest sense, does not (i.e. debris assemblages creeping due to high ground ice content).

Water bodies occur as frozen bodies of water in both study areas. Small frozen ponds occupy circular depressions on debris-covered surfaces (controlled moraines and rock glaciers), but it is not known whether these are semi-permanent or ephemeral features. A frozen lake $\left(0.025 \mathrm{~km}^{2}\right)$ is observed fronting the controlled moraines at the entrance to NHV (Fig. 10e \& f), with other smaller lakes also visible at various ice-marginal positions in both the Hawkes Valleys and
Miller Valley. In SHV a small body of unfrozen water is observed within the U-shaped trough (Fig. 8). In the Miller Valley area larger proglacial lakes front glaciers that flow from the Iroquois Plateau. These glaciers have large areas of controlled moraines at their termini where they are confluent with ice flowing towards Roderick Valley (Figs $2 \& 7$ ). It is inferred that melt is localized and driven by reduced albedo due to proximity to debris or ice-free ground (cf. Dana et al. 1998, Marchant \& Head 2007). No evidence for flowing water was observed except for some small supraglacial channels immediately fronting the large area of controlled moraine north of Miller Valley.

\section{Results of cosmogenic nuclide analyses}

In Miller Valley three samples (MIL-1/2/3) are from the crest of the lowermost portion of the prominent DDA in the southern cirque, $\sim 150 \mathrm{~m}$ from where it is truncated by the upper portion of the feature (Fig. 5). These samples have 


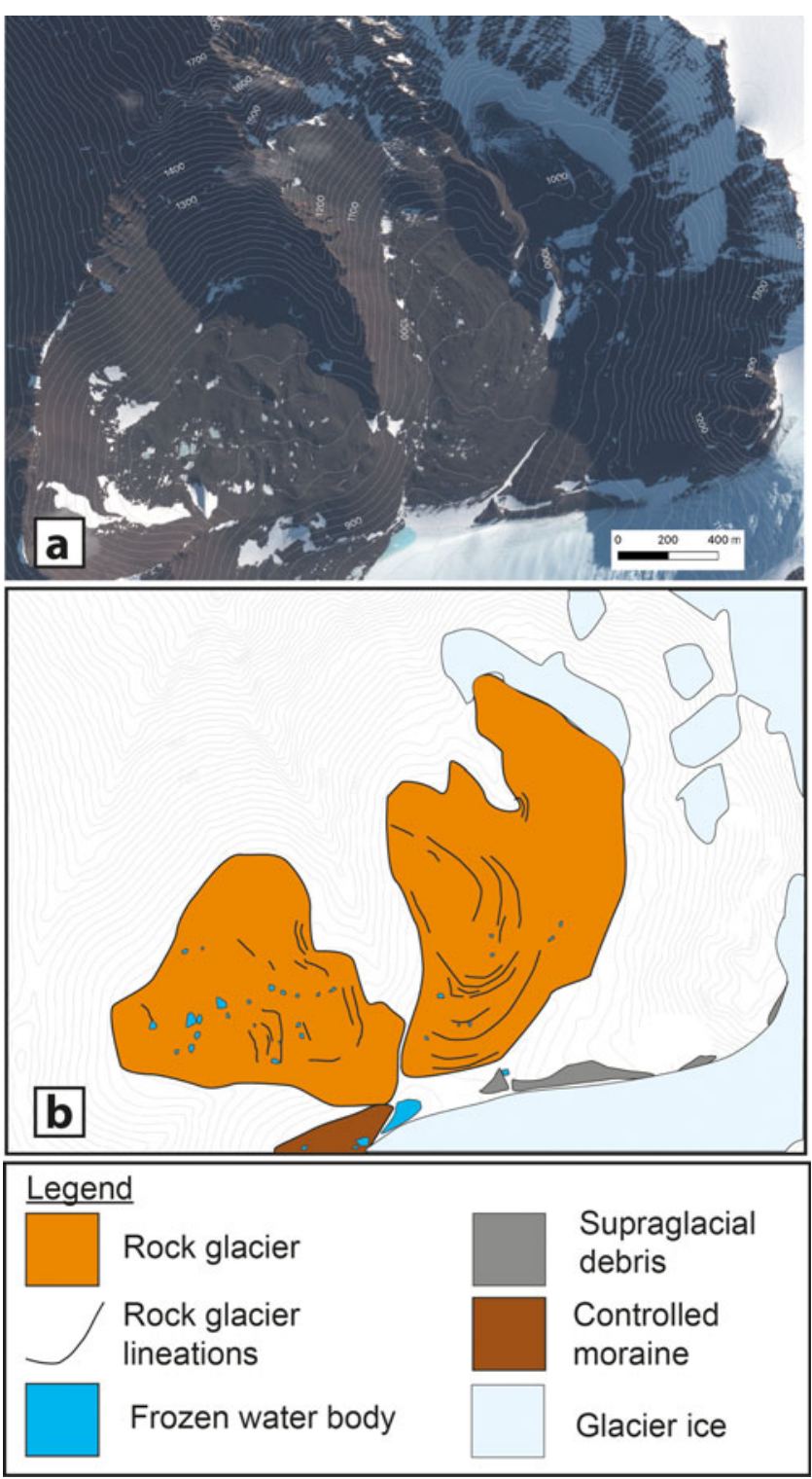

Fig. 11. a. WorldView imagery and b. interpreted map of viscous flow features in cirques immediately south of Mount Hawkes (cf. Fig. 6a).

apparent ${ }^{10} \mathrm{Be}$ exposure ages of 102,251 and $158 \mathrm{ka}$, respectively (Table III). A further three samples (MIL-4/5/6) were collected from the crest of the upper part of the DDA $\sim 500 \mathrm{~m}$ east of MIL-1/2/3. These have comparable apparent exposure ages of 202, 130 and $110 \mathrm{ka}$, respectively (Table III). Four of these samples (MIL-1/2/4/5) have paired ${ }^{26} \mathrm{Al}$ and ${ }^{10} \mathrm{Be}$ analyses and all plot below the steady-state 'erosion island' (Fig. 12).

Two samples (MIL-7/8) were collected from a broad moraine bench/ridge that emerges from beneath the eastern end of the DDA. These samples have significantly older apparent ${ }^{10} \mathrm{Be}$ exposure ages of 1.3 and 1.1 Ma, respectively. A further two samples (MIL-9/10) were collected from heavily weathered till towards the

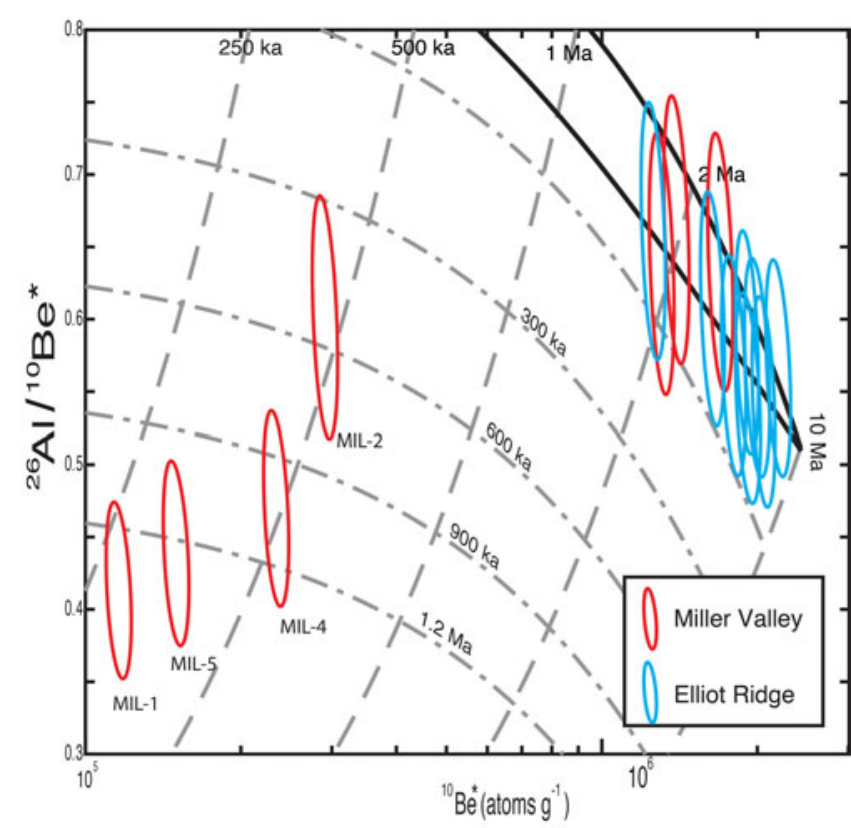

Fig. 12. Two-isotope (banana) plot of normalized $\left({ }^{*}\right){ }^{26} \mathrm{Al} /{ }^{10} \mathrm{Be}$ ratios and ${ }^{10} \mathrm{Be}$ concentrations for all samples with paired ${ }^{26} \mathrm{Al} /{ }^{10} \mathrm{Be}$ analyses.

head of the valley, beyond the outer band of moraines. These samples also have old apparent ${ }^{10} \mathrm{Be}$ exposure ages of 1.4 and $1.9 \mathrm{Ma}$, respectively. Three of these samples have paired ${ }^{26} \mathrm{Al}$ and ${ }^{10} \mathrm{Be}$ analyses and all overlap the steady-state 'erosion island' (Fig. 12).

The samples from Elliot Ridge were collected from elevations of $1168-1427 \mathrm{~m}$, which is $\sim 300-600 \mathrm{~m}$ above the present-day ice surface (700-800 $\mathrm{m}$ a.s.1.). The erratic samples (JON-1/2/5/8/9) were collected from clasts that are visually distinct from the local bedrock and presumably transported and deposited by a former ice sheet(s) that overtopped Elliot Ridge. These samples yield apparent ${ }^{10} \mathrm{Be}$ exposure ages of $1.2-3.0 \mathrm{Ma}$. The bedrock samples (JON-3B/6B/7B) yield similar apparent ${ }^{10} \mathrm{Be}$ exposure ages of $1.8-3.0 \mathrm{Ma}$. All samples from Elliot Ridge have paired ${ }^{26} \mathrm{Al}$ and ${ }^{10} \mathrm{Be}$ analyses and overlap the steady-state 'erosion island' (Fig. 12).

\section{Past glaciation of the Neptune Valleys}

\section{Style of past glaciation}

Due to cold temperatures (Van Wessem et al. 2014) and slow-flowing ice, it is probable that a cold-based thermal regime characterizes the glacial landsystem within the Neptune Valleys, although polythermal conditions could occur where ice accelerates over the escarpment lip (cf. Clarke et al. 1977, Evans \& Rea 2003). In this respect, and given that they terminate at relatively high elevations where the mean annual temperature is very low, the ice 


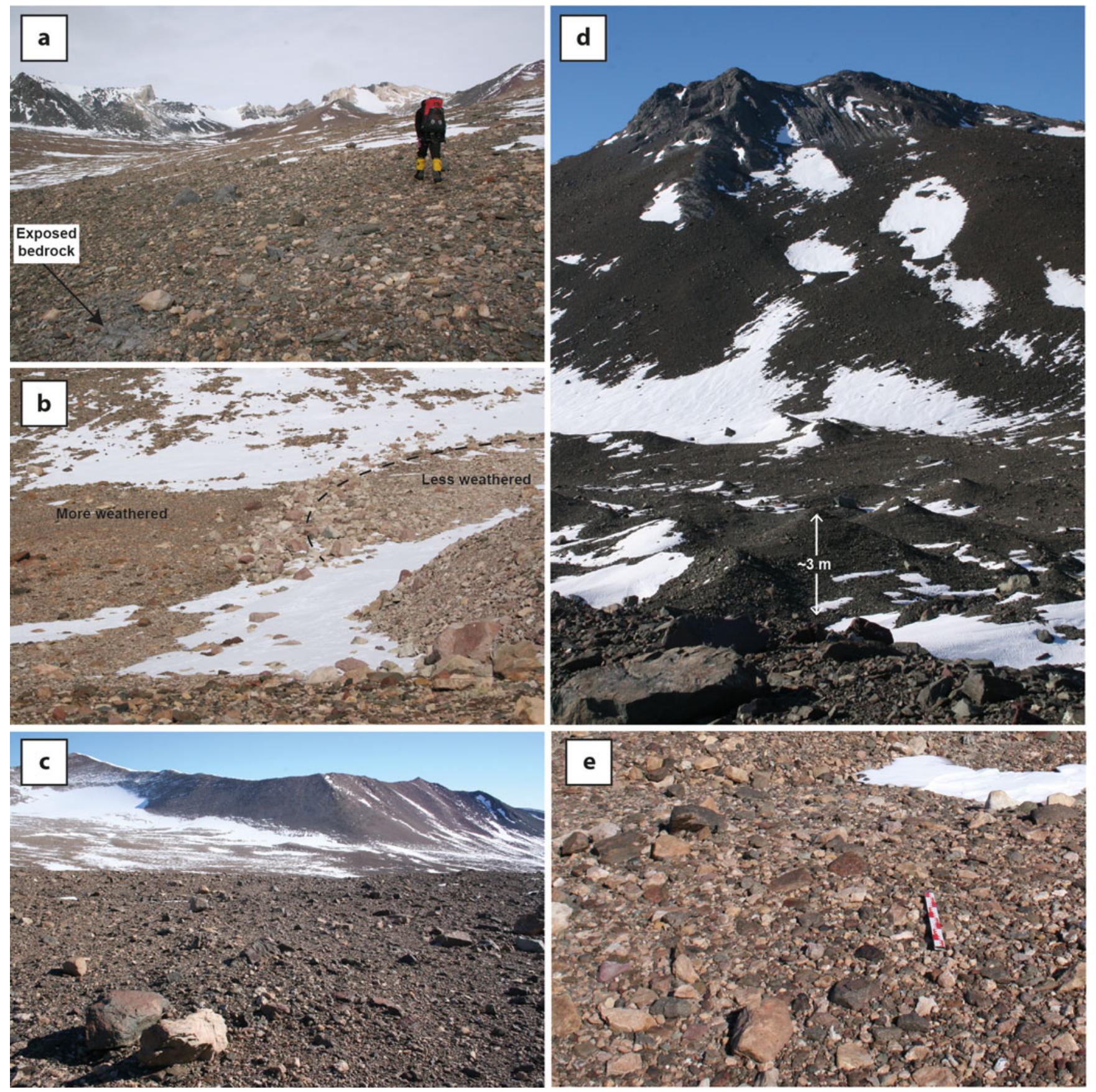

Fig. 13. Field photographs of landforms evidencing cold-based glaciation in Miller Valley and North Hawkes Valley (cf. Tables IV \& V; cf. Atkins, 2013). a. Thin and patchy drift near the ice margin in Miller Valley. Note the bedrock outcropping in the lower right corner of the photograph. b. Inferred trimline or boulder-belt moraine (dashed line) extending trend of the frontal slope of the discrete debris accumulation in Miller Valley. Note the contrast in colour (i.e. weathering) in the material inside/outside this limit. c. Scattered boulders and patchy drift in the upper Miller Valley. Boulders in the foreground are approximately $1 \mathrm{~m}$ in length. d. Debris cones proximal to the active controlled moraine in North Hawkes Valley. e. Potential compressed surface in mid-Miller Valley, metre stick for scale.

masses responsible for the Neptune Valleys landsystem are inferred to be most similar to the Type 3 cold-based glaciers described from South Victoria Land by Atkins (2013). These glaciers are defined as 'Thin, cold-based peripheral lobes connected directly to the (East Antarctic) Ice Sheet or to outlet glaciers draining the ice sheet, [they] rest on the margins of nunataks or extend into the mouths of relict glacial valleys' (Atkins 2013, p. 303). Numerous 
Table V. Depositional landforms related to cold-based glaciation in Antarctica (cf. Atkins 2013) observed in the Neptune Valleys.

\begin{tabular}{|c|c|c|c|}
\hline Landform & Description & Interpretation & Notes \\
\hline Thin patchy drift & $\begin{array}{l}\text { Patchy, discontinuous scattering of } \\
\text { boulders/cobbles }\end{array}$ & $\begin{array}{l}\text { Gentle entrainment, potentially including } \\
\text { overriding of frontal apron (e.g. Shaw 1977, } \\
\text { Evans 1989) }\end{array}$ & $\begin{array}{l}\text { Widely observed in Miller Valley } \\
\text { (n.b. not mapped) }\end{array}$ \\
\hline $\begin{array}{l}\text { Trimline moraine/ } \\
\text { boulder belt }\end{array}$ & Small ridges of clast-supported boulders & $\begin{array}{l}\text { Passive release from ice margin, form ridge if } \\
\text { position maintained. Can form boulder spread due } \\
\text { to time-transgressive retreat }\end{array}$ & $\begin{array}{l}\text { Ridges rare. Curvilinear surface } \\
\text { features (boulders and/or colour } \\
\text { changes) widely observed }\end{array}$ \\
\hline $\begin{array}{l}\text { Scattered } \\
\text { boulders }\end{array}$ & Isolated boulders atop drift deposits & $\begin{array}{l}\text { Plucked from bedrock. Deposited passively during } \\
\text { sublimation-driven retreat }\end{array}$ & $\begin{array}{l}\text { Common in Miller Valley, rarer } \\
\text { examples in North Hawkes Valley } \\
\text { (n.b. not mapped) }\end{array}$ \\
\hline $\begin{array}{l}\text { Ice-cored ridges/ } \\
\text { moraines }\end{array}$ & $\begin{array}{l}\text { Variety of ridges, including large } \\
(>10 \mathrm{~m}) \text { thrust block moraines }\end{array}$ & $\begin{array}{l}\text { Processes include release of basal debris, faulting/ } \\
\text { folding of subglacial substrate and differential } \\
\text { ablation of debris-rich layers }\end{array}$ & $\begin{array}{l}\text { More subdued ridges potentially/ } \\
\text { probably no longer ice cored? }\end{array}$ \\
\hline $\begin{array}{l}\text { Ice-cored debris } \\
\text { cones }\end{array}$ & $\begin{array}{l}\text { Conical debris accumulation found } \\
\text { near to ice margin. Composed of } \\
\text { boulder/sand-grade material }\end{array}$ & $\begin{array}{l}\text { Pockets of englacial debris released from the glacier } \\
\text { front to cover parts of the ice apron }\end{array}$ & Associated with controlled moraines \\
\hline Buried ice & $\begin{array}{l}\text { Subsurface ice, generally within } \\
<1 \mathrm{~m} \text { of the ground surface }\end{array}$ & $\begin{array}{l}\text { Numerous processes ranging from burial of glacier } \\
\text { ice to the formation of interstitial ice in pre-existing } \\
\text { sediment }\end{array}$ & Numerous candidates (e.g. Fig. 19) \\
\hline $\begin{array}{l}\text { Compressed/ } \\
\text { flattened ground }\end{array}$ & $\begin{array}{l}\text { Weathered surface with flattened and } \\
\text { compressed surface }\end{array}$ & Formed by overburden of cold-based ice advance & $\begin{array}{l}\text { Observed in Miller Valley. Could } \\
\text { also reflect surface deflation due to } \\
\text { wind (n.b. not mapped)? }\end{array}$ \\
\hline
\end{tabular}

References: Bockheim et al. (1989), Brook et al. (1993), Sugden et al. (1995), Atkins et al. (2002), Lloyd-Davies et al. (2009), Atkins (2013), Swanger (2017).

geomorphological features are associated with such glaciers and many broadly equivalent landforms are observed in the Neptune Valleys (Fig. 13 \& Table V).

Depositional features related to cold-based ice are strongly controlled by the thermal regime and debris load (Fitzsimons 2003, Evans 2009, Atkins 2013). Assuming a sufficient debris supply, we propose a conceptual model of ice-marginal landform evolution in the Neptune Valleys in Fig. 14. This model should be tested with further investigations, particularly detailed sedimentological analysis of the materials that comprise the relevant landforms to allow comparison to landsystem models proposed for elsewhere in Antarctica (e.g. Hambrey \& Fitzsimons 2010). A further assumption in this model is that the landscape contains old glacier ice, potentially millions of years old (e.g. Sugden et al. 1995, Bibby et al. 2016), which is protected from ablation by supraglacial debris cover created by the melt-out of debris-rich ice folia (cf. blue ice moraines; Altmaier et al. 2010, Bibby et al. 2016). Where it occurs, such buried glacier ice and its debris can be overrun by advancing/steepening glacier fronts, from which it had probably never been completely detached, effectively reconstituting it as a basal debris-rich ice zone. This would result in a distinct subsurface stratigraphy (bands of debris-rich ice concurrent with controlled moraines at the surface). Again, further work involving sedimentological analysis and geophysical surveys is required to test this assumption.

Our model depicts a scenario during glacial (re)advance (Fig. 14a) in which the ice front steepens and relatively fresh debris can be delivered to the glacier snout. The debris transport pathways are along rising englacial folia via debris-rich basal ice facies, which are formed by one or more likely a combination of apron overriding, basal freeze-on and folding/thrusting (Shaw 1977, Evans 1989, Fitzsimons 2003, Fitzsimons et al. 2008), as well as rock fall (Swanger et al. 2011). The development of a cliffed ice margin during advance results in the delivery of debris and ice blocks to the cliff base by falling, to form a dry-calving apron of ice and debris (cf. Evans 1989, Swanger et al. 2017). This apron is then continuously recycled during overriding until the snout cliff downwastes or stabilizes, the latter scenario being significant in that it would result in the accumulation of a more substantial apron and hence a prominent ice-cored moraine ridge (evolving into a trimline moraine over time) within a terrain dominated by more subdued supraglacial debris accumulations.

During recession/downwasting (Fig. 14b) individual controlled moraines form in association with the melt-out of the rising debris-rich ice folia. Where the debris load is high, these controlled moraines can be contiguous, as observed throughout the Neptune Valleys. Such belts of controlled moraine may also be related to the process of incremental stagnation (e.g. Bennett \& Evans 2012), whereby phases of relatively enhanced debris entrainment (e.g. due to changes in basal thermal conditions or influxes of rock slope failure debris) produce 'slugs' of glacial debris that arrive at the ice front sporadically, reducing ablation and forming inset belts of controlled moraine. Depressions that form between controlled 

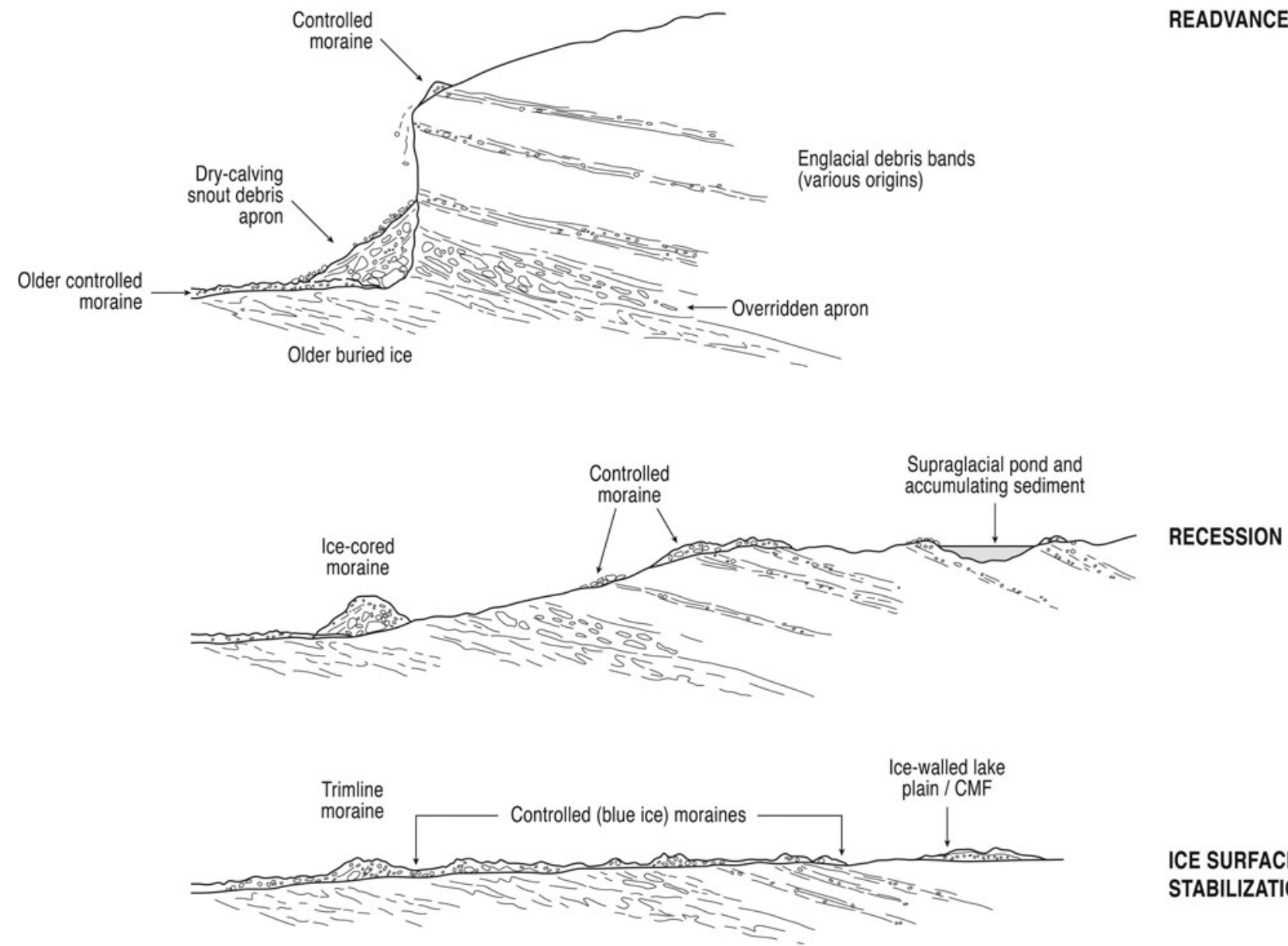

ICE SURFACE STABILIZATION

Fig. 14. Conceptual model of glacial landform formation in the Neptune Valleys. The overall prevalence of landforms will be a function of the debris content of the ice. $\mathrm{CMF}=$ circular moraine feature.

moraines can accumulate water as a result of enhanced melting driven by locally increased albedo; the resulting ponds then become supraglacial sediment traps.

With progressive ablation of near-surface buried ice, controlled moraine ridges are accentuated but also merge and stabilize (Fig. 14c) once the debris cover is sufficiently thick to retard further melting, giving these landform high preservation potential (cf. Hambrey \& Fitzsimons 2010). Former cliffed ice-margin locations can be delimited by trimline or boulder-belt moraines. Additionally, former debris-charged ice-marginal zones, potentially representing either climatically driven glacier advances or phases of incremental stagnation, can be delimited by zones of controlled moraine and/or DDAs.

\section{Evidence of the former ice extent in Miller Valley}

Erratic clasts are present within heavily weathered drift deposits (Fig. 15a) at the uppermost location visited within Miller Valley. This indicates that the ice sheet has previously filled much of Miller Valley (e.g. Limit 1,
Fig. 16). There is further evidence for this in the form of faint drift limits on the southern valley side that dip towards the valley head (Fig. 15b). Any ice sheet that reached Limit 1 (Fig. 16) at the head of Miller Valley must have been $\sim 300 \mathrm{~m}$ thicker than the present-day ice sheet. In the upper cirque some indistinct mounds (Fig. 7; Limit 3A, Fig. 16) potentially represent ice limits, but it cannot be determined whether they represent ice-sheet flow into Miller Valley or expansion of a small glacier sourced in the upper cirque.

Inside the most expansive proposed ice limit (Limit 1) a distinct band of moraine ridges on the main valley floor delimit a more restricted ice-sheet expansion(s) of $2.3 \mathrm{~km}$ produced by ice $\sim 180 \mathrm{~m}$ thicker than present (Limit 2, Fig. 16). Further subtle ridges on the valley floor may represent a subsequent retreat stage or a separate, less extensive ice-sheet expansion into Miller Valley (Limit 3B, Fig. 16). Evidence for ice-sheet expansion is also found in the unnamed valley to the north of Miller Valley where there is a distinct lobate-shaped DDA (Fig. 7). The plan-form of this deposit suggests that it was 

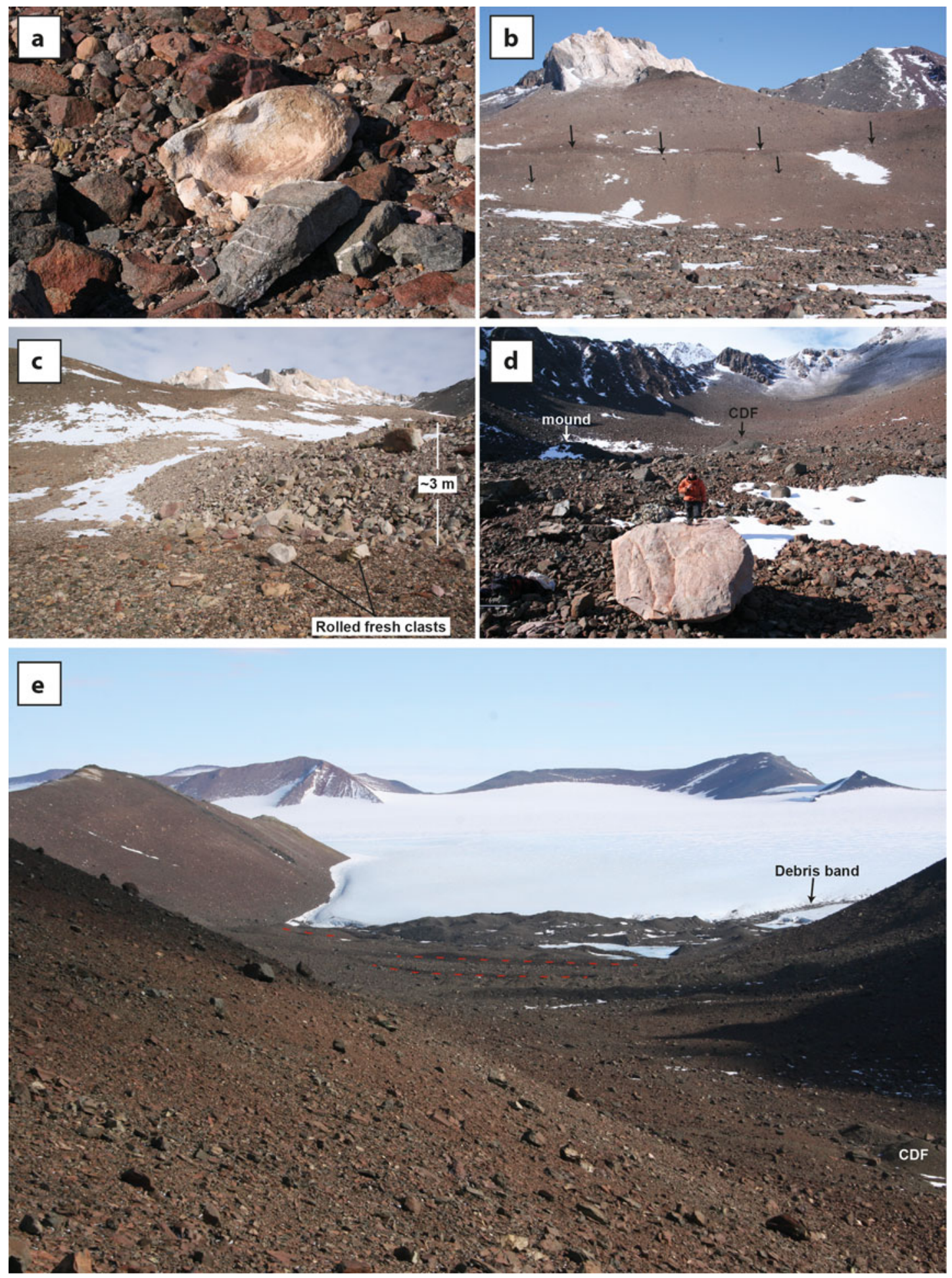

Fig. 15. Field photographs of evidence for expanded ice in Miller Valley and North Hawkes Valley (NHV). a. Varied lithology of heavily weathered patchy drift in the upper Miller Valley, near the sample site of MIL-9/10. Large boulders are $\sim 0.5 \mathrm{~m}$ in length. b. Potential trimlines/drift limits (arrowed) on the flank of the upper Miller Valley, looking approximately south from sample location of MIL-9/ 10. c. Frontal slope of the discrete debris accumulation in Miller Valley where it crosscuts the older moraine bench. Note where the fresher clasts have apparently rolled off this feature and now sit atop older and more weathered material. d. Large erratic boulder in the central NHV. The uppermost mound (in shadow with snow) and the circular depositional feature (CDF; in sun) are visible in the mid-background. The person is $\sim 2 \mathrm{~m}$ in height. e. Looking down NHV towards the controlled moraine and ice margin, the medial debris band is visible on the right-hand side of the ice tongue. Note the uppermost CDF in the lower right and the sequence of moraine ridges (red dashed lines) stepping back towards the present-day ice margin. The main ice flow in the background is from right to left. 


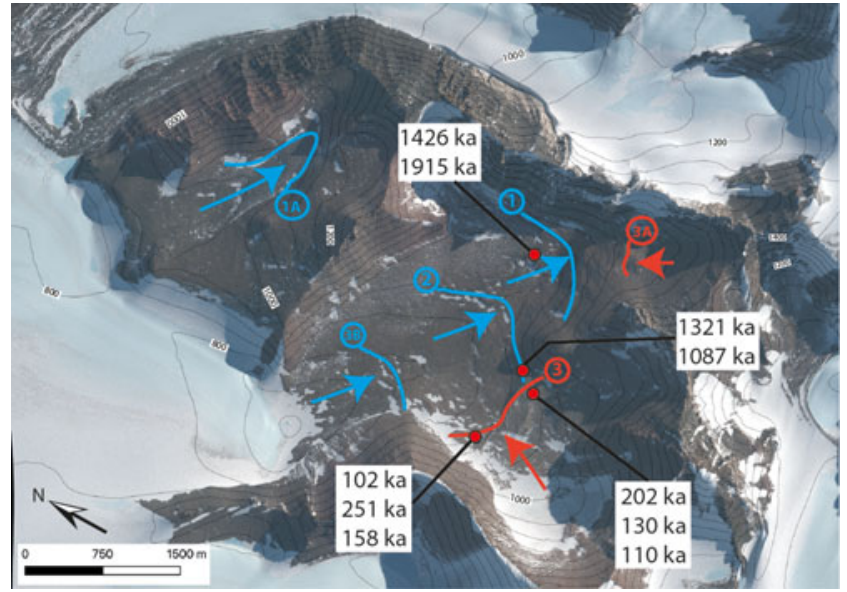

Fig. 16. Schematic depiction of postulated ice limits in Miller Valley. Blue denotes postulated ice-sheet advance and red denotes postulated local glacier advance. Ages shown are individual ${ }^{10} \mathrm{Be}$ exposure ages from different cobbles/boulders at the four locations within Miller Valley (cf. Table III).

emplaced by a tongue of ice that extended into the valley at a time when the main ice sheet was at least $240 \mathrm{~m}$ thicker than it is today (Limit 1A, Fig. 16).

There is also evidence for expansion of a locally nourished glacier in the form of the large DDA located where the southern cirque opens onto the main floor of Miller Valley. The frontal face of the DDA is steep and in places fresh, unweathered clasts have rolled off and now lie on darker, more weathered drift (Fig. 15c). This feature appears to be composite in nature with an upper unit overlying a smaller lower unit (e.g. Fig. 5a). However, there is no difference in apparent exposure ages or the degree of weathering of the constituent materials so the significance of this relationship is not known. We note that the deposit is predominantly composed of pale sedimentary rocks. The source area of the cirque glacier also consists of pale rocks that contrast with the darker mudstones that make up the opposite (northern) side of the valley. Thus it is inferred that this feature relates to expansion of the small cirque glacier that presently occupies the upper part of the southern cirque (Limit 3, Fig. 16).

\section{Evidence of the former ice extent in the Hawkes Valleys}

NHV contains a distinct sequence of moraines, debris mounds and CDFs (Fig. 8) that evidence ice-sheet advance(s) of $\sim 2-3 \mathrm{~km}$ into the valley. These expansions would be associated with an ice sheet that was at least 140-160 m thicker than present (Limit 1, Fig. 17). Evidence for distinct ice-marginal positions is more sparse in CHV, although CDFs and a pair of moraine ridges towards the valley head (Fig. 8) provide clear evidence of ice expansion of $\sim 3 \mathrm{~km}$ up the valley

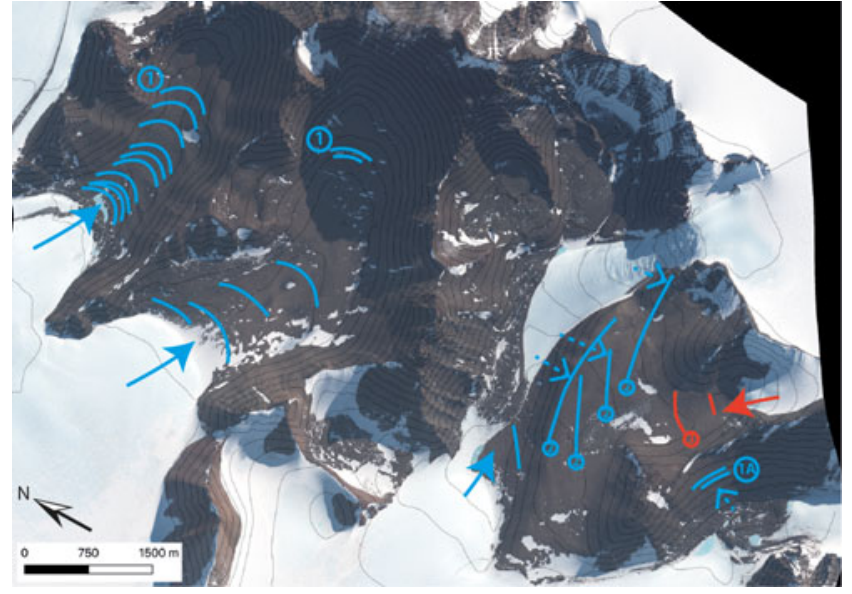

Fig. 17. Schematic depiction of postulated ice limits in Hawkes Valley. Dashed arrows denote postulated ice thickening. Blue denotes postulated ice-sheet advance and red denotes postulated local glacier advance.

(Limit 1, Fig. 17). Notably this would require ice at least $160 \mathrm{~m}$ thicker than present, in close accord with the estimate from field evidence in NHV. Evidence for a broadly equivalent thickening is also found in a presently ice-filled valley immediately south of SHV where moraine ridges on the valley side (Fig. 8) record ice that was $\sim 200 \mathrm{~m}$ thicker than present (Limit 1A, Fig. 17).

In SHV the evidence for expanded ice is more complex. Moraines parallel to the lateral margin of the overtopping outlet glacier demonstrate that it previously thickened to flow onto the raised bench that comprises the southern portion of the valley (Fig. 8). Further moraine ridges, mounds and a DDA on the bench surface record multiple ice-margin positions (Limits 2, Fig. 17). It is probable that these reflect interactions between the overtopping glacier and thicker ice at the valley entrance. When confluent this ice would have filled the U-shaped valley and, when thick enough, spilled onto the bench as evidenced by the sub-parallel orientation of ridges on the bench surface (Fig. 8). Some subtle ridges observed in the small valley re-entrant on the southern margin of the bench may be related to an expansion of the small cirque glacier (Limit 3, Fig. 17) that remains at the valley head, although these are now mostly covered in aeolian sand dunes.

Overall, the pattern of ice expansion appears broadly similar in both Miller Valley and the Hawkes Valleys. The orientation of ice-contact features records advance(s) of ice into the valleys by an ice sheet consistent with an expanded margin from the present-day ice configuration. In Miller Valley there is also clear evidence for an expansion of a small cirque glacier, with more ambiguous evidence also present in SHV. It is notable that there is no clear evidence for much thicker ice on the Iroquois 
Plateau overtopping the Washington Escarpment and flowing into the heads of the main valleys.

\section{Preliminary geochronological constraints on ice-sheet history}

Ten samples are from Miller Valley and eight samples are from the crest of Elliot Ridge, $\sim 11.5 \mathrm{~km}$ south-west of the Hawkes Valleys. Cosmogenic nuclide samples in Antarctica are often affected by nuclide inheritance; however, paired nuclide measurements allow for the assessment of potential complex exposure histories. The location of samples on a two-isotope plot (Fig. 12) can inform on their past exposure-burial history. Samples that plot within the steady-state erosion island are consistent with (but do not mandate) simple continuous exposure under steady-state erosion. Samples that plot below the erosion island must have experienced at least one period of burial.

The apparent ${ }^{10} \mathrm{Be}$ exposure ages from Miller Valley fall into two broad age windows. Six younger ages (MIL-1/6: $102-251 \mathrm{ka})$ are from the crest of different parts of the DDA. However, it is not possible to determine whether there is any significant age difference from the available age constraints. Four samples (MIL-1/2/4/5) with paired nuclide analyses exhibit complex exposure histories (Fig. 12) with minimum burial durations of $\sim 300 \mathrm{ka}-1.2 \mathrm{Ma}$. In contrast, the other samples (MIL-7/10) are from a subdued moraine exhibiting increased weathering (MIL-7/8) and a weathered drift sheet more distal to present-day ice (MIL-9/10). These samples have significantly older exposure ages, all exceeding $1 \mathrm{Ma}$. Three samples with paired nuclide analyses (MIL-7/9/10) have ${ }^{26} \mathrm{Al} /{ }^{10} \mathrm{Be}$ ratios that are consistent with continuous exposure. It is of particular note that MIL-7/8 were sampled from a moraine bench that emerges from beneath, and thus clearly predates, the DDA from which the younger exposure ages were obtained. Additionally, it is notable that the materials that comprise both the moraine bench and the drift sheet are significantly more weathered with increased occurrences of wind polish, tafoni and cavernous weathering (Fig. 6).

This evidence, alongside the mapped geomorphology, suggests that there have been multiple (at least two) advances of ice within Miller Valley, producing the two broad groupings of apparent exposure ages and ${ }^{26} \mathrm{Al} /{ }^{10} \mathrm{Be}$ ratios (Fig. 12 \& Table III). The simplest explanation for the observed pattern is that early ice-sheet advance(s) into the valley deposited the drift sheet and moraine bench where samples MIL-7/10 were located. Subsequently, these samples were continuously exposed for $>1 \mathrm{Ma}$. Later advance(s) of the small glacier within the southern cirque must have occurred $>100-250 \mathrm{ka}$ based on the apparent ${ }^{10} \mathrm{Be}$ exposure ages. This advance(s) entrained debris that had been previously exposed and subsequently buried to form the DDA from where the samples exhibiting complex exposure were collected. The reality is probably more complex, with multiple ice advances of both the ice sheet and local cirque glaciers. However, it can be inferred that any later ice-sheet advances were either more restricted (not reaching the locations of MIL-7/10) or were short lived and thus undetectable using the ${ }^{26} \mathrm{Al} /{ }^{10} \mathrm{Be}$ nuclide pair.

Multiple advances separated by significant amounts of time would also explain the differing moraine morphologies and degrees of weathering. It is notable that the surficial material in NHV also displays increased weathering with distance from the present-day ice margin (Fig. 18). In both valley systems there are multiple ice-margin locations that relate to both ice-sheet expansion into the valleys and expansion of local glaciers. Given this, and considering the cosmogenic nuclide data from Miller Valley, we infer that the Neptune Valleys contain a multimillion-year record of glacial advances in this sector of the West Antarctic Ice Sheet (WAIS).

All of the samples from Elliot Ridge have old apparent ${ }^{10} \mathrm{Be}$ exposure ages $(\sim 1.2-3.0 \mathrm{Ma})$ and overlap with the erosion island on the two-isotope plot (Fig. 12). This implies continuous and prolonged exposure of Elliot Ridge during the Plio-Pleistocene. Notably, both erratic and bedrock samples produce comparable results. The simplest explanation of these data is that the last erosive ice sheet to override Elliot Ridge produced the large-scale ice-moulded bedrock observed (Fig. 6). It is possible (although not mandated by the data) that this ice sheet also emplaced the erratics. Alternatively, these erratics may have been emplaced by later cold-based ice-sheet expansion(s) that were sufficiently brief to be undetectable using the ${ }^{26} \mathrm{~A} /{ }^{10} \mathrm{Be}$ nuclide pair. Evidence elsewhere in the Pensacola Mountains demonstrates that the ice sheet was several hundred metres thicker within the main flow conduits (e.g. FIS, Academy Glacier) at least once in the past: during the Last Glacial Maximum (e.g. Bentley et al. 2017). Taking our data at face value, this expansion, and any other prior expansions that postdate erratic emplacement, must have been either insufficient to overtop Elliot Ridge or brief and cold-based.

The old apparent exposure ages from the bedrock samples imply that the initial overriding by an erosive ice sheet occurred $>2-3 \mathrm{Ma}$. Accounting for even a small amount of erosion $\left(0.5 \mathrm{~m} \mathrm{Ma}^{-1}\right)$ in the exposure age calculations renders all samples from Elliot Ridge saturated. Small amounts of sub-aerial erosion occur in Antarctica (Marrero et al. 2018) and evidence for erosion is observed on Elliot Ridge. Consequently, the age of warm-based ice-sheet overriding and emplacement of the erratics is likely to be very much older than the apparent exposure ages. 

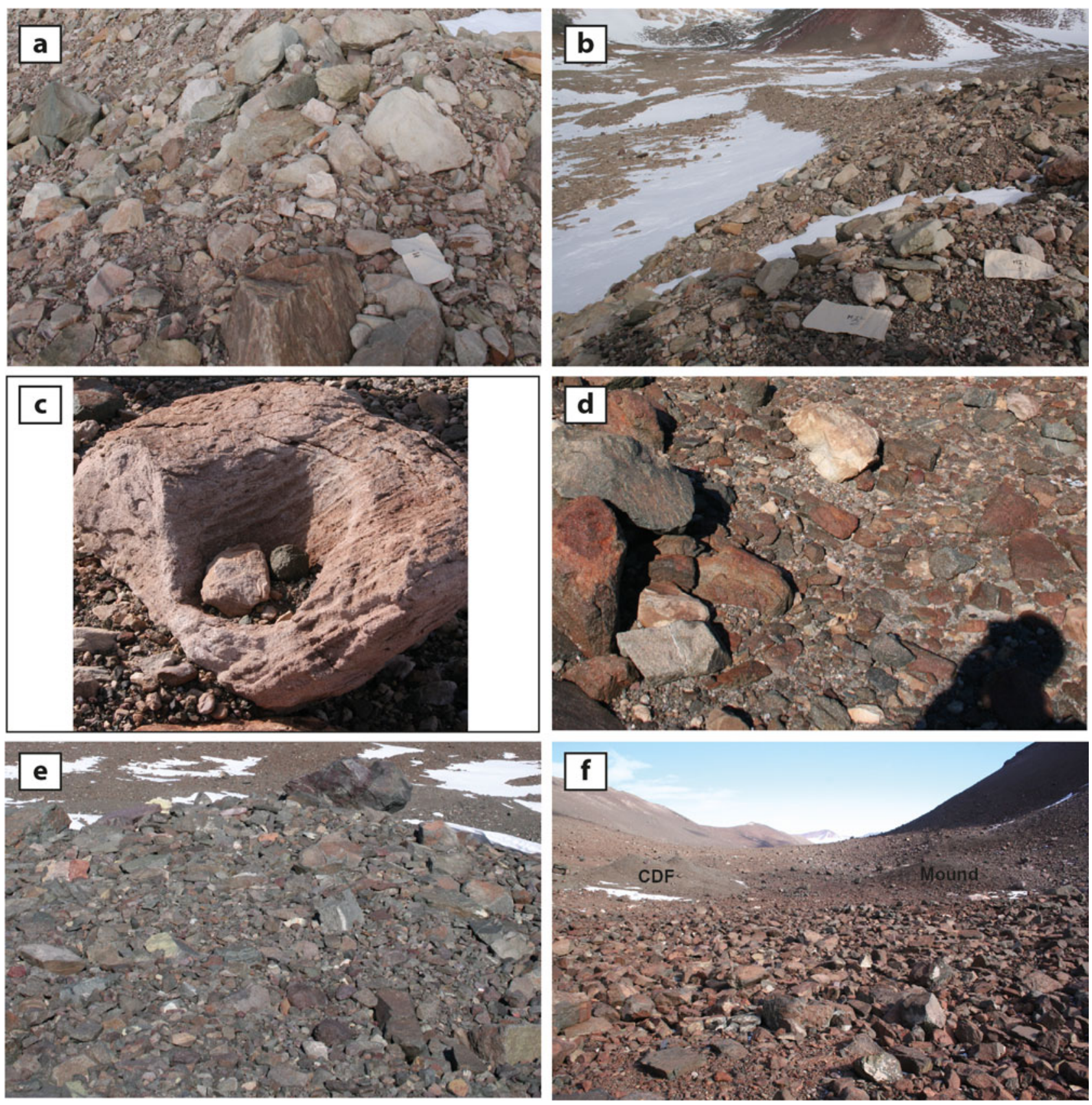

Fig. 18. Field photographs from Miller Valley and North Hawkes Valley (NHV) showing contrasts in degree of weathering. a. Material comprising the surface of the discrete debris accumulation in Miller Valley. Sample MIL-4 is visible immediately left of the cloth bag (sample bag is $\sim 0.3 \mathrm{~cm}$ in length). b. Material at sample site of MIL-1/2, with no clear difference from the material in a. (sample bags $\sim 0.3 \mathrm{~m}$ in length) c. Cavernous weathering observed on the floor of the main valley inside the outermost ridges. Boulder measures $\sim 0.5 \mathrm{~m}$ across. d. Surficial material in the upper Miller Valley, beyond the outermost band of ridges on the valley floor. Note the contrast with the materials in panels a. and b. e. Fresh material on the moraine ridge in the lower NHV. Note the contrast with f., which shows weathered material beyond the uppermost mound (right) and circular depositional feature (CDF; left) in NHV.

\section{Comparison to the glacial chronology of Dufek Massif}

Based on geomorphological observations and direct dating control $\left({ }^{26} \mathrm{Al}\right.$ and $\left.{ }^{10} \mathrm{Be}\right)$, a sequence of glacial stages (Stages 1-7; Table VI) have been proposed to describe a multimillion-year record (Miocene-Pleistocene) of ice- sheet evolution in Dufek Massif, $180 \mathrm{~km}$ north-northeast of the Neptune Range (Hodgson et al. 2012). Given their relative proximity, it is possible to make some speculative correlations between the glacial chronologies in the two areas. Initial alpine-style glaciation (Stage 1; cf. 
Table VI. Glacial stages inferred from geomorphological evidence in Dufek Massif (Hodgson et al. 2012) and their potential equivalents in the Neptune Valleys.

\begin{tabular}{|c|c|c|c|}
\hline Glacial stage & Description (cf. Hodgson et al. 2012) & Potential equivalent evidence in Neptune Range & Age constraint \\
\hline 1 & Alpine glaciation & Cirques and arêtes incised in Washington Escarpment & Early Miocene $^{a}$ \\
\hline 2 & Warm-based ice-sheet overriding & Ice moulding on Elliot Ridge & $>>2-3 \mathrm{Ma}$ \\
\hline 3 & Outlet glacier and ice-sheet advance & Emplacement of erratics on Elliot Ridge? & $>>2-3 \mathrm{Ma}$ \\
\hline 4 & Extensive ice-sheet advance & $\begin{array}{l}\text { Deposition of uppermost drift sheet in Miller Valley } \\
\text { (Limit 1, Figs } 13 \text { \& 14) }\end{array}$ & $>2 \mathrm{Ma}$ \\
\hline 5 & Less extensive ice-sheet advance & $\begin{array}{l}\text { Deposition of moraine ridges, mid-Miller Valley } \\
\text { (e.g. Limit 2, Fig. 13). }\end{array}$ & $>1.0-1.3 \mathrm{Ma}$ \\
\hline 6 & Advance/retreat of outlet glaciers & Deposition of DDA in Miller Valley (e.g. Limit 3, Fig 13) & $<250 \mathrm{ka}$ \\
\hline 7 & Advance/retreat of current ice-sheet configuration & $\begin{array}{l}\text { Deposition of freshest moraines in NHV (e.g. Limit 3B in } \\
\text { Miller Valley)? }\end{array}$ & LGM or earlier $^{a}$ \\
\hline
\end{tabular}

${ }^{a}$ Inferred.

DDA = discrete debris accumulation; LGM = Last Glacial Maximum; NHV = North Hawkes Valley.

Hodgson et al. 2012) is inferred to have produced arêtes and cirques, and such features are observed along the majority of the length of the Washington Escarpment. A subsequent major glacial expansion (Stage 2) by a warm-based ice sheet resulted in overriding of the entire landscape in Dufek Massif and is inferred to be of Miocene age (Hodgson et al. 2012). It is possible that this event is represented in the Neptune Range by the ice-moulded bedrock and old bedrock exposure ages from Elliot Ridge. Later, short-lived cold-based expansions (Stage 3?) may have emplaced the erratics on Elliot Ridge. Subsequent advances of the ice sheet probably did not subsume the entire landscape and are constrained to be older than 1.0-2.0 Ma (Stages 4 and 5). Equivalent events are potentially represented by the older exposure ages from Miller Valley. Finally, more restricted advances (Stages 6 and 7) of the ice margin and outlet glaciers are inferred to have occurred since Marine Isotope Stage 5, and these are possibly the equivalent of the young exposure ages from Miller Valley and the fresh moraines observed in NHV. The broad similarity in event stratigraphy emerging from two different parts of the Pensacola Mountains reinforces the inference that ice-free areas in the Neptune Range record a regional signal of ice-sheet history over millions of years.

\section{Analogues elsewhere}

The nearest comparable ice-free areas are the Davis and Forlidas dry valleys in Dufek Massif. These valleys also occur in the lee of an escarpment displaying alpine-like topography. Additionally, extensive glacial deposits and moraines delimit multiple ice expansions into the valleys. Other similarities include the development of frost-sorted polygons, with differential stages of maturation, and differential weathering of glacial deposits. One significant contrast is that the Dufek valleys have evidence for running, liquid water produced by the melting of ice and snow (Hodgson et al. 2012). In the Neptune Valleys rare instances of liquid water were observed in sheltered depressions on the surface of the controlled moraines in NHV and some melt channels on the ice surface were observed at the margin of the distinct belt of controlled moraines north of Miller Valley. A single example of a small melt pond is observed in SHV. There is no evidence for running water or former lakes/ponds on the valley

Table VII. Distinctive geomorphic features, landforms and erosion rates for each microclimate zone in the McMurdo Dry Valleys (MDVs) and the Neptune Valleys.

\begin{tabular}{|c|c|c|c|c|}
\hline & Neptune Valleys & $\begin{array}{l}\text { MDVs Stable Upland } \\
\text { Zone }\end{array}$ & $\begin{array}{l}\text { MDVs Inland Mixed } \\
\text { Zone }\end{array}$ & $\begin{array}{l}\text { MDVs Coastal Thaw } \\
\text { Zone }\end{array}$ \\
\hline $\begin{array}{l}\text { Mean (summer) annual } \\
\text { temperature }\left({ }^{\circ} \mathrm{C}\right)\end{array}$ & -27 (modelled) & $(-10)-22$ & $(-7)-18$ & $(-5)-20$ \\
\hline $\begin{array}{l}\text { Thermal contraction } \\
\text { features }\end{array}$ & $\begin{array}{l}\text { Deep troughs and high centres observed } \\
\text { (sublimation type) }\end{array}$ & $\begin{array}{l}\text { Sublimation-type } \\
\text { polygons }\end{array}$ & $\begin{array}{l}\text { Sand-wedge and } \\
\text { composite polygons }\end{array}$ & Ice-wedge polygons \\
\hline Flow features & Rock glaciers & Debris-covered glaciers & Gelifluction lobes & Solifluction lobes \\
\hline Bedrock erosion rate ${ }^{a}$ & $\sim 0.2-0.3 \mathrm{~m} \mathrm{Ma}^{-1}$ (Elliot Ridge) & $\sim 0.06-0.27 \mathrm{~m} \mathrm{Ma}^{-1}$ & Mixed & $\sim 1 \mathrm{~m} \mathrm{Ma}^{-1}$ \\
\hline $\begin{array}{l}\text { Additional features/ } \\
\text { processes }\end{array}$ & $\begin{array}{l}\text { Rectilinear slopes, lack of gullying, } \\
\text { cavernous weathering and pitted clast } \\
\text { surfaces }\end{array}$ & $\begin{array}{l}\text { Pitted surface cobbles, } \\
\text { salt-cemented } \\
\text { duricrusts, puzzle } \\
\text { rocks and relict gullies }\end{array}$ & $\begin{array}{l}\text { Desert pavements with } \\
\text { wind-polished cobbles } \\
\text { and immature, } \\
\text { closely spaced gullies }\end{array}$ & $\begin{array}{l}\text { Thermokarst, tafoni and } \\
\text { low-gradient } \\
\text { slopes with mature, } \\
\text { low-density } \\
\text { gullies }\end{array}$ \\
\hline
\end{tabular}

\footnotetext{
${ }^{a}$ Erosion rates for MDVs from Brook et al. (1995) and Summerfield et al. (1999).
} 

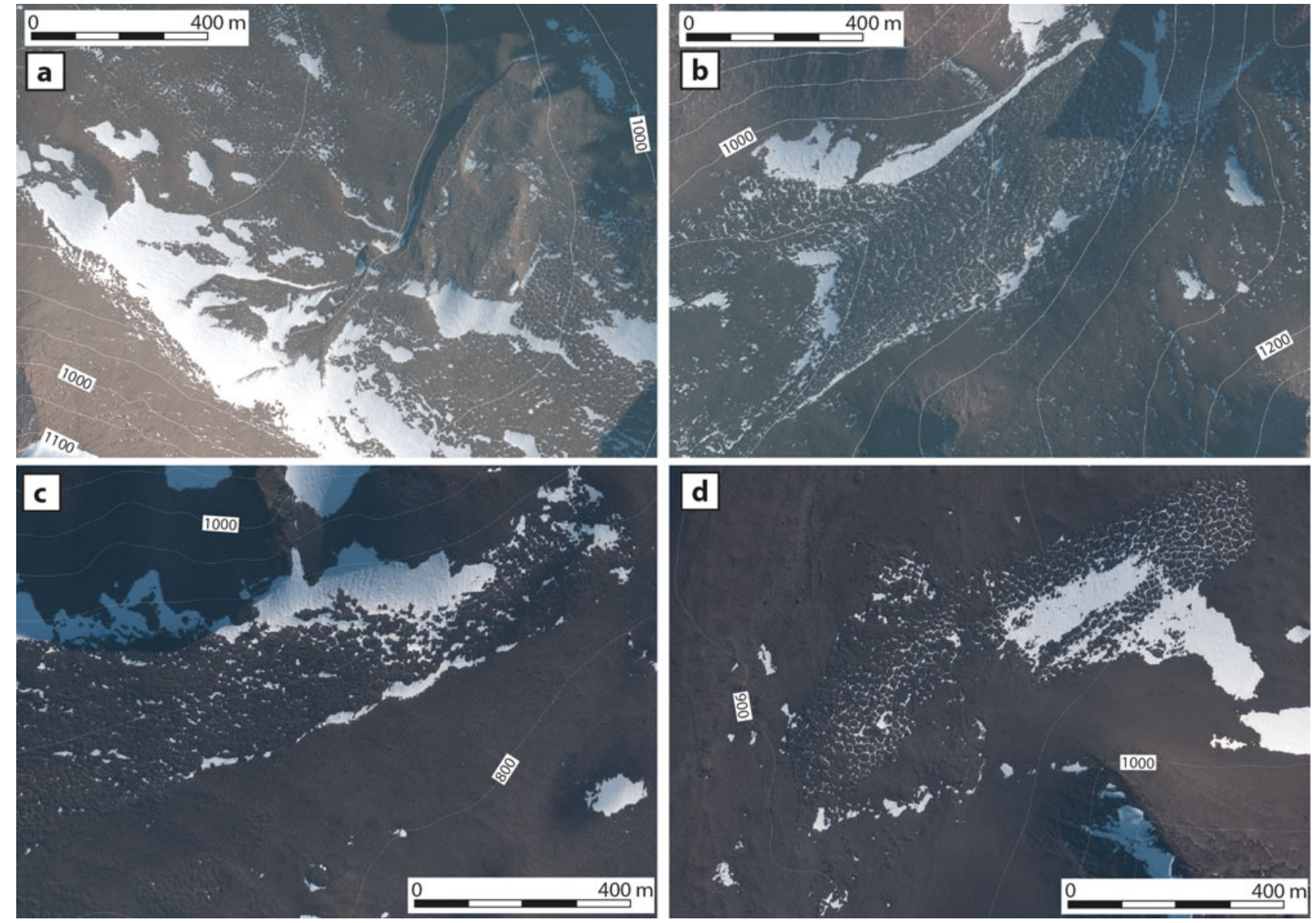

Fig. 19. Satellite imagery of potential locations of buried ice. a. Discrete debris accumulation (DDA) in Miller Valley. High-centred polygons are visible in the lower right of the image. b. Lobate DDA in the unnamed valley north of Miller Valley. c. Lateral DDA in Central Hawkes Valley. The edge of this feature is delimited by a scarp face $\sim 3 \mathrm{~m}$ in height. d. DDA in South Hawkes Valley. Note the moraine mounds and ridges at the margins of this feature. Also note the polygonized (deep trough high centres) surfaces generally associated with these features, akin to sublimation-type polygons (Marchant et al. 2002). A small scarp face is just visible above the labelled $900 \mathrm{~m}$ contour.

floors themselves despite both $\mathrm{CHV}$ and NHV having topographical depressions on the valley floor. Compared to the Dufek valleys, the Neptune Valleys are at higher altitudes $(\sim 700-1000 \mathrm{~m}$ vs $300-500 \mathrm{~m})$ and are located further into the interior of the Weddell Sea embayment. The lower temperatures at these elevations, along with high rates of sublimation (Das et al. 2013), preclude melting except in sheltered locations with significantly increased albedo (cf. Dana et al. 1998, Marchant \& Head 2007). The lack of relict meltwater features and palaeoshorelines (cf. Hodgson et al. 2012) suggests that this general absence of liquid water has been a persistent feature within the valleys.

The best-studied Antarctic dry valleys, the MDVs, have been characterized into three geomorphic zones on the basis of temperature and the occurrence of surface meltwater (Table VII; Marchant \& Head 2007). Meteorological data are not available for the Neptune Valleys, thus it is not possible to make a direct comparison on this basis. However, we note that the modelled mean annual temperature $\left(-27^{\circ} \mathrm{C}\right.$; Van Wessem et al. 2014) is akin to the Stable Upland Zone and, given the large distance to the coast, direct precipitation is likely to be very low. On the basis of the geomorphological features identified within the Neptune Valleys we suggest that they are most closely aligned with the Stable Upland Zone of the MDVs (Table VII). The presence of viscous flow features (rock glaciers) that are akin to debris-covered glaciers and potential sublimation-type polygons, along with the absence of running water and gullying on valley sides, support this inference, but more detailed observations are required to confirm it.

Overall, the glacial landsystem model proposed for the Neptune Valleys reflects similarities to cold polythermal glacier forelands in the Arctic (cf. Goldthwait 1951, Evans 1989, 2009). In these settings the occurrence of icemarginal landforms is strongly controlled by ice-rich debris 
facies/folia and their melt-out in the ice-marginal zone. The progressive accumulation of debris reduces ablation during glacier downwasting to produce zones of ice-cored controlled moraines. Over relatively short time scales, buried ice melts out in the Arctic settings and there is significant reworking by both thermokarst and fluvial processes (e.g. Dyke \& Evans 2003). In contrast, in the extreme cold and aridity of Antarctica, melt-out is retarded or even stopped by the accumulating supraglacial debris, giving rise to the development of remarkably old, inset sequences of controlled moraines (blue ice moraines).

\section{Potential of the Neptune Valleys}

The Neptune Valleys are a rare ice-free location within the interior of the Weddell Sea embayment. Their location in an area of Antarctica susceptible to major change (cf. Pollard \& DeConto 2009) makes them a potentially valuable archive. The geomorphological records presented here provide several potential avenues for future research.

Firstly, the Neptune Valleys contain moraine sequences evidencing ice expansion(s) that, based on initial cosmogenic exposure ages and observed weathering contrasts, potentially span multimillion-year time scales. It is not clear whether ice advance into the valleys is driven by local ice thickening in Roderick Valley/ Iroquois Plateau (potentially controlled by local precipitation) or larger-scale ice-sheet dynamics with significantly thicker ice in the trunks of the major flow conduits (FIS and Academy Glacier). However, Miller Valley and potentially SHV contain evidence for expansion of local cirque glaciers, suggesting that the Neptune Valleys may contain a record of climate-driven local glacier dynamics. Such a record would be rare in this sector of Antarctica (cf. Hodgson et al. 2012). In the MDVs, moraine sequences have improved our understanding of the response of Antarctic mountain glaciers to climate, providing a rare terrestrial archive of palaeoenvironmental change (Swanger et al. 2011, 2017). Specifically, they have highlighted an anti-phasing between advances of terrestrial (East Antarctic) glaciers and retreats/collapses of the marine-based WAIS during globally warm periods such as the mid-Pliocene, Marine Isotope Stage 31 and Marine Isotope Stage 11 (Swanger et al. 2011, 2017). To date, this relationship has only been identified in the Ross Sea sector of Antarctic. The Neptune Valleys are a potential location to test whether a similar anti-phasing exists in the Weddell Sea sector and represents a continent-wide response of the Antarctic cryosphere to global climate change.

Additionally, the MDVs are located only $\sim 70 \mathrm{~km}$ from the present-day grounding line of the FIS in the Weddell Sea embayment. This region of Antarctica is highly susceptible to change and is expected to have experienced significant ice-sheet retreat during previous collapses of the WAIS (Pollard \& DeConto 2009). It might be hypothesized that such a collapse would allow moisture to penetrate further into the interior, and, particularly in combination with a warmer climate, this might leave a geomorphic fingerprint within the Neptune Valleys.

Another potential palaeoenvironmental archive is the assemblage of rock glaciers that are present in both study areas within the Neptune Valleys. The best-studied examples of rock glaciers and debris-covered glaciers in Antarctica are in the MDVs. Geophysical, geochemical and geomorphological studies of viscous flow features within the MDVs have revealed that due to low sublimation rates they can be long-lived features (e.g. $10^{5}-10^{6}$ years; Marchant et al. 2002, Mackay \& Marchant 2017) and that the origin of the ice within them can vary with local climatic conditions (e.g. Swanger et al. 2010). Consequently, these features have potential as long-term palaeoenvironmental archives (e.g. Mackay \& Marchant 2017), and study of the internal structure, geochemical composition and age of the features in the Neptune Valleys could be informative.

Finally, buried ice is common in polar settings characterized by cold-based glaciations and is widely observed in the MDVs (e.g. Sugden et al. 1995) and other dry valley systems in Antarctica (e.g. Bibby et al. 2016). Such ice bodies have potential to shed light on past glacial, hydrological and climatic conditions and are potentially valuable palaeoenvironmental archives. Where buried ice is proximal $(<1 \mathrm{~m})$ to the surface, polygons can form due to temperature-driven contraction during winter (Marchant et al. 2002). The two main polygon morphologies produced are low-relief sand-wedge polygons and, where massive buried ice bodies exist, high-relief sublimation polygons with high centres and deep troughs (cf. Marchant \& Head 2007). Polygons with such morphologies are observed in several locations in the Neptune Valleys (Fig. 19) and highlight sites where buried ice may be present. Additionally, the overall configuration of the valleys is broadly similar to Ong Valley in the central Transantarctic Mountains where cosmogenic nuclide measurements have identified multiple buried ice bodies aged $>1.5 \mathrm{Ma}$. These valleys share a broad valley floor that rises gently from the ice blocking their entrances. Such a setting makes it improbable that any buried ice body can be replenished from the modern glacier (Bibby et al. 2016). Thus, if such an ice body survives, it has good potential as a palaeoenvironmental archive. We note that the Neptune Valleys do not appear to have distinct lobes of polygonized sublimation till as observed in Ong Valley; however, the evidence for ice advance into the valleys is clear and areas of polygons do exist across large areas of the valley floors. Given the multimillion-year evolution of the Neptune Valleys, the investigation of the potential presence of buried ice should be a priority for any future 
research visits, as there are currently no such records from this Atlantic-influenced sector of Antarctica.

\section{Conclusions}

In the lee of highpoints on the Washington Escarpment are ice-free areas that contain a variety of geomorphological features. Preliminary geomorphological mapping reveals numerous landforms that are related to expansions of ice into the valleys and, potentially, expansions of local cirque glaciers. The expansions of ice into the valleys were produced by an ice sheet with a configuration broadly similar to present (cf. Schmidt et al. 1978). Preliminary cosmogenic nuclide data and observed weathering contrasts suggest that the Neptune Valleys contain a multimillion-year record of ice-sheet history. The evidence for potential buried ice and controlled moraines within this area and the abundance of geomorphological features that can reflect past environmental change back to the Late Pliocene highlight that the Neptune Valleys are a source of potentially valuable terrestrial archives from a sector of Antarctica where such records are rare.

\section{Acknowledgements}

We thank the British Antarctic Survey pilots and operations staff who facilitated the work in the Pensacola Mountains. Particular thanks are given to James Wake for his assistance in the field. We would like to acknowledge Chris Orton (Design and Imaging Unit at Durham University), who produced the final draft of Fig. 17. We would like to thank two anonymous reviewers whose constructive comments improved a previous version of the manuscript.

\section{Author contributions}

DS mapped and interpreted the glacial geomorphology, calculated exposure ages and interpreted the results. MJB undertook fieldwork and collected cosmogenic nuclide samples. DJAE advised on the interpretation of the glacial geomorphology. ASH prepared the cosmogenic nuclide samples and collated sample chemistry data. SPHTF undertook accelerator mass spectrometry analysis of the samples. DS led the manuscript preparation and produced tables and figures, with the exception of Fig. 14. DJAE drafted Fig. 14. All authors contributed to the initial draft of the manuscript and provided reviews and feedback that led to the final submission version.

\section{Financial support}

The work reported here forms part of NERC grants NE/ F014260/1, NE/F014252/1 and NE/F014228/1 to MJB. DS is supported by a NERC Independent Research Fellowship NE/T011963/1.

\section{References}

Altmaier, M., Herpers, U., Delisle, G., Merchel, S. \& Ott, U. 2010. Glaciation history of Queen Maud Land (Antarctica) reconstructed from in-situ produced cosmogenic ${ }^{10} \mathrm{Be},{ }^{26} \mathrm{Al}$, and ${ }^{21} \mathrm{Ne}$. Polar Science, 4, 10.1016/j.polar.2010.01.001.

Atкins, C.B. 2013. Geomorphological evidence of cold-based glacier activity in South Victoria Land, Antarctica. In M.J. HAMBreY, P.F. Barker, P.J. Barrett, V. Bowman, B. Davies, J.L. Smellie \& M. Tranter, eds. Antarctic palaeoenvironments and Earth-surface processes. Special Publication of the Geological Society of London, No. 381, 10.1144/SP381.18.

Atkins, C.B., Barrett, P.J. \& Hicock, S.R. 2002. Cold glaciers erode and deposit: evidence from Allan Hills, Antarctica. Geology, 30, 10.1130/ 0091-7613(2002)030<0659:CGEADE>2.0.CO;2.

BenN, D.I. \& Evans, D.J.A. 2010. Glaciers and glaciation. London: Routledge, $816 \mathrm{pp}$.

Bennett, G.L. \& Evans, D.J.A. 2012. Glacier retreat and landform production on an overdeepened glacier foreland: the debris-charged glacial landsystem at Kviárjökull, Iceland. Earth Surface Processes and Landforms, 37, 10.1002/esp.3259.

Bentley, M.J., Hein, A.S., Sugden, D.E., Whitehouse, P.L., Shanks, R., Xu, S. \& Freeman, S.P.H.T. 2017. Deglacial history of the Pensacola Mountains, Antarctica from glacial geomorphology and cosmogenic nuclide surface exposure dating. Quaternary Science Reviews, 158, 10.1016/j.quascirev.2016.09.028.

Bibby, T., Putkonen, J., Morgan, D., Balco, G. \& Shuster, D.L. 2016. Million year old ice found under meter thick debris layer in Antarctica. Geophysical Research Letters, 43, 10.1002/2016GL069889.

Bockheim, J.G., Wilson, S.C., Denton, G.H., Andersen, B.G. \& STuiver, M. 1989. Late Quaternary ice-surface fluctuations of Hatherton Glacier, Transantarctic Mountains. Quaternary Research, 31, 10.1016/0033-5894(89)90007-0.

Brook, E.J., Brown, E.T., Kurz, M.D., Ackert, R.P., JR, Raisbeck, G.M. \& YIOU, F. 1995. Constraints on age, erosion, and uplift of Neogene glacial deposits in the Transantarctic Mountains determined from in situ cosmogenic ${ }^{10} \mathrm{Be}$ and ${ }^{26} \mathrm{Al}$. Geology, 23, 10.1130/ 0091-7613(1995)023<1063:COAEAU>2.3.CO;2.

Brook, E.J., Kurz, M.D., Ackert, R.P., Jr, Denton, G.H., Brown, E.T., Raisbeck, G.M. \& Yiou, F. 1993. Chronology of Taylor Glacier advances in Arena Valley, Antarctica, using in situ cosmogenic ${ }^{3} \mathrm{He}$ and ${ }^{10}$ Be. Quaternary Research, 39, 10.1006/qres.1993.1002.

Clarke, G.K.C., Nitzan, U. \& Paterson, W.S.B. 1977. Strain heating and creep instability in glaciers and ice sheets. Reviews of Geophysics and Space Physics, 15, 10.1029/RG015i002p00235.

Clayton, L., Attig, J.W., Ham, N.R., Johnson, M.D., Jennings, C.E. \& Syverson, K.M. 2008. Ice-walled-lake plains: implications for the origin of hummocky glacial topography in middle North America. Geomorphology, 97, 10.1016/j.geomorph.2007.02.045.

Cuffey, K.M., Conway, H., Gades, A.M., Hallet, B., Lorrain, R., Severinghaus, J.P., et al. 2000. Entrainment at cold glacier beds. Geology, 28, 10.1130/0091-7613(2000)28<351:EACGB>2.0.CO;2.

DANA, G.L., Wharton, R.A., JR \& DubAYAH, R. 1998. Solar radiation in the McMurdo Dry Valleys, Antarctica. Antarctic Research Series, 72, 39-64.

Das, I., Bell, R.E., Scambos, T.A., Wolovick, M., Creyts, T.T., Studinger, M., et al. 2013. Influence of persistent wind scour on the surface mass balance of Antarctica. Nature Geoscience, 6, 10.1038/ ngeo1766.

Denton, G.H. \& Sugden, D.E. 2005. Meltwater features that suggest Miocene ice-sheet overriding of the Transantarctic Mountains in Victoria Land, Antarctica. Geografiska Annaler - Physical Geography, 87A,10.1111/j.0435-3676.2005.00245.x.

Dyke, A.S. \& Evans, D.J.A. 2003. Ice-marginal terrestrial landsystems: northern Laurentide and Innuitian ice sheet margins. In D.J.A. Evans, ed. Glacial landsystems. London: Arnold, 143-165. 
Dyke, A.S. \& SAVelle, J.M. 2000. Major end moraines of Younger Dryas age on Wollaston Peninsula, Victoria Island, Canadian Arctic: implications for paleoclimate and for formation of hummocky moraine. Canadian Journal of Earth Sciences, 37, 10.1139/e99-118.

Ebert, K. \& Kleman, J. 2004. Circular moraine features on the Varanger Peninsula, northern Norway, and their possible relation to polythermal ice sheet coverage. Geomorphology, 62, 10.1016/ j.geomorph.2004.02.009.

EvANS, D.J.A. 1989. The nature of glacitectonic structures and sediments at sub-polar glacier margins, northwest Ellesmere Island, Canada. Geografiska Annaler - Physical Geography, 71A, 10.1080/ 04353676.1989.11880280.

Evans, D.J.A. 2009. Controlled moraines: origins, characteristics and palaeoglaciological implications. Quaternary Science Reviews, 28, 10.1016/j.quascirev.2008.10.024.

Evans, D.J.A. \& ReA, B.R. 2003. Surging glacier landsystem. In D.J.A. Evans, ed. Glacial landsystems. London: Arnold, 259-288.

Fitzsimons, S.J. 2003. Ice-marginal terrestrial landsystems: polar continental glacier margins. In D.J.A. Evans, ed. Glacial landsystems. London: Arnold, 89-110.

Fitzsimons, S.J., Webb, N., Mager, S., MacDonell, S., Lorrain, R. \& SAMYN, D. 2008. Mechanisms of basal ice formation in polar glaciers: an evaluation of the apron entrainment model. Journal of Geophysical Research, 113, 10.1029/2006JF000698.

Goldthwait, R.P. 1951. Development of end moraines in east-central Baffin Island. Journal of Geology, 59, 10.1086/625912.

Hambrey, M.J. \& Fitzsimons, S.J. 2010. Development of sedimentlandform associations at cold glacier margins, Dry Valleys, Antarctica. Sedimentology, 57, 10.1111/j.1365-3091.2009.01123.x.

Hodgson, D.A., Bentley, M.J., Schnabel, C., CZiferszkry, A. Fretwell, P., Convey, P. \& Xu, S. 2012. Glacial geomorphology and cosmogenic ${ }^{10} \mathrm{Be}$ and ${ }^{26} \mathrm{Al}$ exposure ages in the northern Dufek Massif, Weddell Sea embayment, Antarctica. Antarctic Science, 24, 10.1017/S0954102012000016.

Howat, I.M., Porter, C., SMith, B.E., Noh, M.J. \& Morin, P. 2019. The reference elevation model of Antarctica. The Cryosphere, 13, 10.5194/ tc-13-665-2019.

Jones, R.S., Small, D., Cahill, N., Bentley, M.J. \& Whitehouse, P.L. 2019. iceTEA: tools for plotting and analysing cosmogenic-nuclide surface-exposure data from former ice margins. Quaternary Geochronology, 51, 10.1016/j.quageo.2019.01.001

KoHL, C.P. \& Nishizzumi, K. 1992. Chemical isolation of quartz for measurement of in-situ-produced cosmogenic nuclides. Geochimica et Cosmochimica Acta, 56, 10.1016/0016-7037(92)90401-4.

Lewis, A.R., Marchant, D.R., Ashworth, A.C., Hemming, S.R. \& Machlus, M.L. 2007. Major middle Miocene global climate change: evidence from East Antarctica and the Transantarctic Mountains. Geological Society of America Bulletin, 119, 10.1130/0016-7606 (2007)119[1449:MMMGCC]2.0.CO;2.

Lifton, N., SAto, T. \& DunaI, T.J. 2014. Scaling in situ cosmogenic nuclide production rates using analytical approximations to atmospheric cosmic-ray fluxes. Earth and Planetary Science Letters, 386, 10.1016/j.epsl.2013.10.052.

Lloyd-Davies, M.L., Atkins, C.B., van der Meer, J.J.M., Barrett, P.J. \& Hicock, S.R. 2009. Evidence for cold-based glacial activity in the Allan Hills, Antarctica. Quaternary Science Reviews, 28, 10.1016/ j.quascirev.2009.08.002.

Lukas, S., Nicholson, L.I., Ross, F.H. \& Humlum, O. 2005. Formation, meltout processes and landscape alteration of high arctic ice-cored moraines - examples from Nordenskiold Land, central Spitsbergen. Polar Geography, 29, 10.1080/789610198.

MackaY, S.L. \& Marchant, D.R. 2017. Obliquity-paced climate change recorded in Antarctic debris-covered glaciers. Nature Communications, 8, 10.1038/ncomms14194.
Marchant, D.R. \& Head, J.W., III. 2007. Antarctic dry valleys: microclimate zonation, variable geomorphic processes, and implications for assessing climate change on Mars. Icarus, 192, 10.1016/j.icarus.2007.06.018.

Marchant, D.R., Lewis, A.R., Phillips, W.M., Moore, E.J., Souchez, R.A., Denton, G.H., et al. 2002. Formation of patterned ground and sublimation till over Miocene glacier ice in Beacon Valley, southern Victoria Land, Antarctica. Geological Society of America Bulletin, 114, 10.1130/0016-7606(2002)1 14<0718:FOPGAS>2.0.CO;2.

Marrero, S.M., Hein, A.S., NaYlor, M., Attal, M., Shanks, R., Winter, K., et al. 2018. Controls on subaerial erosion rates in Antarctica. Earth and Planetary Science Letters, 501, 10.1016/j.epsl.2018.08.018.

Ó Cofaigh, C., Evans, D.J.A. \& England, J. 2003. Ice-marginal terrestrial landsystems: sub-polar glacier margins of the Canadian and Greenland High Arctic. In D.J.A. Evans, ed. Glacial landsystems. London: Arnold, 45-64.

Pollard, D. \& DeConto, R.M. 2009. Modelling West Antarctic Ice Sheet growth and collapse through the past five million years. Nature, 458, 10.1038/nature07809.

RaIns, R.B. \& Shaw, J. 1981. Some mechanisms of controlled moraine development, Antarctica. Journal of Glaciology, 27, 10.3189/ S0022143000011278.

Rignot, E., Mouginot, J. \& Scheuchl, B. 2011. MEaSUREs InSAR-based Antarctica ice velocity map. Science, 333, 10.1126/ science. 1208336.

Schmidt, D.L., Williams, P.L. \& Nelson, W.H. 1978. Geologic map of the Schmidt Hills quadrangle and part of the Gambacorta Peak quadrangle, Pensacola Mountains, Antarctica (No. 8). Reston, VA: US Geological Survey.

SHAW, J. 1977. Till body morphology and structure related to glacier flow. Boreas, 6, 10.1111/j.1502-3885.1977.tb00348.x.

Sugden, D.E., Marchant, D.R., Potter, N., JR, Souchez, R.A., Denton, G.H., Swisher, C.C., III \& Tison, J.L. 1995. Preservation of Miocene glacier ice in East Antarctica. Nature, 376, 10.1038/ $376412 \mathrm{a} 0$.

Summerfield, M.A., Stuart, F.M., Cockburn, H.A.P., Sugden, D.E., Denton, G.H., Dunai, T. \& Marchant, D.R. 1999. Long-term rates of denudation in the Dry Valleys, Transantarctic Mountains, southern Victoria Land, Antarctica based on in-situ-produced cosmogenic ${ }^{21} \mathrm{Ne}$. Geomorphology, 27, 10.1016/S0169-555X(98) 00093-2.

Swanger, K.M. 2017. Buried ice in Kennar Valley: a late Pleistocene remnant of Taylor Glacier. Antarctic Science, 29, 10.1017/ S0954102016000687.

Swanger, K.M., Marchant, D.R., Kowalewski, D.E. \& Head, J.W., III. 2010. Viscous flow lobes in central Taylor Valley, Antarctica: origin as remnant buried glacial ice. Geomorphology, 120, 10.1016/ j.geomorph.2010.03.024.

SWanger, K.M., Lamp, J.L., Winckler, G., Schaefer, J.M. \& Marchant, D.R. 2017. Glacier advance during Marine Isotope Stage 11 in the McMurdo Dry Valleys of Antarctica. Scientific Reports, 7, 10.1038/srep41433.

Swanger, K.M., Marchant, D.R., Schaefer, J.M., Winckler, G. \& HEAD, J.W., III. 2011. Elevated East Antarctic outlet glaciers during warmer-than-present climates in southern Victoria Land. Global and Planetary Change, 79, 10.1016/j.gloplacha.2011.07.012.

Van Wessem, J.M., Reijmer, C.H., Morlighem, M., Mouginot, J., Rignot, E., Medley, B., et al. 2014. Improved representation of East Antarctic surface mass balance in a regional atmospheric climate model. Journal of Glaciology, 60, 10.3189/2014JoG14J051.

Whalley, W.B. 2009. On the interpretation of discrete debris accumulations associated with glaciers with special reference to the British Isles. In J. KNIGHT \& S. Harrison, eds. Periglacial and paraglacial processes and environments. Special Publication of the Geological Society of London, No. 320, 10.1144/SP320.7. 